\title{
The factors that influence customer e-services adoption
}

\author{
Kamisha Persad*, Keshnee Padayachee ${ }^{\dagger}$ \\ *School of Computing, University of South Africa \\ †Institute for Science and Technology Education, University of South Africa
}

\begin{abstract}
The aim of this paper is to provide an overview of the investigation into customer e-service adoption. The investigation includes a qualitative survey and observation of participants using e-services. E-services are used to attract customers and persuade them to transact online and the customer's perception of an e-service contributes greatly to e-service adoption or rejection. This paper describes the factors that influence customer perception towards e-services. Relationships between the identified factors were also considered in order to build a conceptual framework. Grounded theory was used for its flexibility, repetitive comparisons of data, and emergence of concepts and theories.
\end{abstract}

KEYWORDS: Customer e-services adoption, enabler, inhibitor, customer satisfaction

CATEGORIES:

H.5.4 [Information interfaces and presentation]: Hypertext/hypermedia-user issues

K.4.4 [Computers and society]: Electronic commerce-distributed commercial transactions

\section{ARTICLE HISTORY}

Received 11 November 2013

Accepted 27 June 2015

\section{INTRODUCTION}

An e-service is essentially a service 'whose delivery is mediated by information technology' [1]. Customer e-service adoption occurs when the e-service concerned satisfies the customer's requirements and persuades the customer to return to the e-service. To foster customer e-service adoption, the following factors must be considered: delivery performance, time saving, website functional properties, Internet familiarity, money saved, risk, customer support and product variety [2]. The factors that inhibit customer e-services adoption are: techno-stress [3], system failures, an increase in perceived risks, and low online security to protect confidential data 4]. It is essential for organisations and managers to understand - from a customer's perspectivethe factors that either inhibit or foster the adoption of e-services. The aim of this research is to develop a conceptual framework to describe the relationship between the factors that influence customer e-service adoption. The study will allow organisations to understand their customers' needs and thus improve customer e-service.

Customers are drawn towards e-services due to the convenience of, for example, the booking of flights, shopping and banking online [4. Online self-service

Email: Kamisha Persad kamishapersad@gmail.com, Keshnee Padayachee padayk@unisa.ac.za eliminates geographic barriers [5] and allows customers the convenience of shopping anywhere in the world via an e-service. Customers want convenience, product variety, affordable products, high-performing and userfriendly systems, relevant information, and minimised risk from e-services 2. Perceived risks, in other words where customers are reluctant to complete online transactions due to the fear of online risks, hinder the use of e-services. Risks are categorised as: performance risk, financial risk, time risk, psychological risk, social risk and privacy risk [4. The lack of security implemented online is a factor that greatly concerns customers [6], and e-service adoption by customers is greater where self-service offers both convenience and high security. The customer's perception of online risks plays a vital role in e-service adoption.

Customers experience techno-stress when technology is complex, difficult to use and constantly changing 3]. Tarafdar et al. 3] investigated the impact of emerging information and communication technology (ICT) on end-user satisfaction. A techno-stress creator, such as information overload, decreases customer e-service adoption. Another techno-stress creator has in recent times been increasing numbers of system failures [7]. A techno-stress inhibitor, on the other hand, is the assurance that online technical support is available.

To be successful, service providers must identify the requirements of their customers [8]. In this way, 
the service provider creates a positive impression with the customer. The use of the Internet and self-service technologies is increasing in South Africa and across the world 9 . Hence, customers are more knowledgeable with regard to e-services and this makes them more demanding in terms of receiving a high quality of service.

The motivation for this study lies in the increased use of the Internet. Shoppers today demand convenience, the need to save time and money and ability to avoid any form of risk. This study does not only benefit online shoppers, it also helps organisations to better understand customers. A good understanding of customers' needs leads to improved customer services.

This article presents the results of a grounded theory study undertaken to identify the factors that influence e-service adoption. The aim was to build a conceptual framework to identify the relationships between the factors that influence e-service adoption. The rest of the paper is structured as follows: Section 2 presents related work on the factors that influence e-service adoption; the research methodology is explicated in Section 3. Section 4 describes the techniques used to collect data. Section 5 provides an overview of the analysis of the data collected. A discussion of the analysis is in Section 6. The proposed framework is discussed in Section 7. Section 8 relates to the significance of the conceptual framework. Section 9 contains a detailed discussion on validity and reliability. Finally, a summary of the findings and future research directions are proposed in Sections 10 and 11.

\section{RELATED WORK}

The customer's perception of the usefulness of an online service increases customer adoption of the e-service [10]. According to Kandampully [1] organisations compete on the basis of services rendered, 'and not on the basis of physical products delivered'. However, Lee and Joshi 2 illustrate a different view to e-service and argue that face-to-face interaction is more effective in resolving customer dissatisfaction. Hence it is imperative for organisations to understand the factors that influence e-service adoption.

\subsection{Delivery performance and the time factor}

The infrastructure setup is linked directly to the speed of the e-service, that is, the faster the network service, the faster the performance of the e-service [7. Many e-services are rejected by customers due to poor system design, which leads to very slow system response [12. E-services that have a high system performance (i.e. that save time) are more likely to be used by the customer. Time can be saved in the following ways: by providing relevant content to the customer, by ensuring that the content is presented well and is easy to navigate, by ensuring that the customer's needs are met, and by providing a high performing infrastructure for the e-service 12. An e-service that saves time invariably increases the likelihood that the customer will adopt the use of such a service.

\subsection{Elimination of barriers}

Geography and location are no longer restricting factors in doing business and attracting new customers. E-services makes it possible to offer a 'variety of services' from 'anywhere in the world, around the clock' thus 'creating value in the supply chain by the reduction of many of the barriers to entry' [13.

The fact that customers are able to access a service online from anywhere in the world does pose security risks and customers fear that their personal information will be misused and they may not have recourse as laws and regulations are not applied uniformly across countries 14.

\subsection{Trust, loyalty and social influence}

If the network speed is excellent and does not frustrate the user, if the relevant information is easily available to customers, if online help is available, and if the system is user friendly, customers develop an increasing amount of trust in a service provider's technology [15. Perceived security and privacy also influences customer trust 15. Customer trust will increase customer loyalty, which can be expected to result in future profit gain. Customer loyalty can also be ensured by customising the service offering and being responsive to customer problems [16. Bitner et al. 7] suggests that outcomes such as customer satisfaction and loyalty may be ensured by: guaranteeing quick recovery from system failure; 'spontaneous delight', (i.e. offering a service or reward that pleasantly surprises the customer) and customisation. Kassim and Abdullah 16 found that the antecedents of loyalty are usability, security and the 'attractiveness' of the website. Customer loyalty and trust are also increased by social influence. This occurs when satisfied customers refer the e-service - social influence is highly valued as shopping online is perceived as risky [17. Social influence reduces the cost of maintaining customer loyalty, and an increase in customer loyalty usually leads to an increase in customer e-service adoption.

\subsection{Customer preference and customisation}

Customisation of e-services is definitely an advantage in the field of technology. An example of a customised e-service is Streamline - an online grocery store 7 . The store has created a competitive advantage by identifying every customer's preferences and buying patterns, determining when the customer needs another order/delivery (based on the last purchase date) and generally adding value for customers. Through awareness of its customers' preferences, this e-service increases customer satisfaction by rendering the desired service [7]. Although it is costly to maintain customisations as compared to merely offering generic functionalities 18, the customers' needs are met and these satisfied customers return to do more business. 


\subsection{Techno-stress}

Constant changes and complex customisations increase techno-stress 19. Techno-stress creators are those factors that introduce stress into an information technology environment 20]. For example, communication overload and information overload are techno-stress creators where users are faced with too many electronic services. Keeping track of the latest technology trends and coping with the complexities of newer electronic devices are also causes of such stress [20]. Technostress inhibitors, on the other hand, are ways to prevent techno-stress. For instance, technical support and help desks reduce techno-stress [19]. Techno-stress creators and inhibitors would unquestionably influence the adoption of e-services.

\subsection{Recovery from system failure and online customer support}

The technology infusion matrix proposed by Bitner et al. focuses on the following areas:

1. Response to customer needs and requests (customisation and flexibility). It is important to understand the customer's needs and preferences.

2. Response to service delivery and system failures. The time taken to assist customers during system failures affects an organisation's reputation and subsequent customer loyalty.

3. Unprompted or unsolicited actions (spontaneous delight). This involves providing customers with a pleasing experience that they did not expect. [7]

The following tools that are used to assist customers increase the likelihood of e-service adoption: Video response systems, help-desk applications [7, e-mail and telephone contact details [2].

\subsection{Usability factors}

Two constructs identified by Demangeot and Broderick 21] that enhance customer adoption are: sensemaking (intuitiveness, screen clarity, content relevance etc.) and exploratory potential (visual impact, context familiarity, site-user understanding etc.). The empirical research by Christobal et al. shows that there is a need to develop user-friendly websites to generate 'higher satisfaction and loyalty levels' 22. Feather and Pavlou 4 found that customers are likely to return to user-friendly e-services as the perceived ease of use reduced performance risk concerns.

\subsection{Satisfying customer requirements}

The philosophy behind Total quality management (TQM) is 'total organisational involvement in all aspects of the quality of product or service by an organisation' 23. Ward 24] proposed using TQM to develop information system requirements as it may be used to ensure that customers' needs are met first time, every time. TQM can be used to deliver 'information products and services that meet or exceed defined requirements', and focuses on the customer requirements by regularly monitoring customer service satisfaction and offering management involvement to ensure that the organisation understands the customer 24]. Chou 25 recommends the use of TQM to increase customer retention in e-commerce as it customer-centric. Similar to the TQM method, Kano's model of customer satisfaction also places emphasis on the customer's requirements [26]. The Kano model has been applied to e-services by several researchers. [27, 28, 29]. Zhang and von Dran [29] recommend the Kano model for determining customer quality expectations, as it can evolve with time, as the e-service evolves.

Kano's model [30] was built on the following three factors that influence customer satisfaction: 'mustbe' quality, one-dimensional quality and attractive quality. An increase in customer satisfaction increases loyalty [31]. The Kano model which was related to e-services quality by Zhang and von Dran [29] includes the following:

- Basic features - expected requirements of users.

- Performance features-requirements that persuade users 'stay in the game' (e.g. support for different platforms).

- Exciting features - requirements that are unexpected but cause 'excitement' among users (i.e. 'spontaneous delight' 7])

These two methods may be used to drive customer requirement specifications. Integrating TQM in ecommerce can result in lowering costs and increasing sales 25]. The dimension of the Kano model is well suited to e-services as a model, as it facilitates the transition of an 'attractive' requirement to a 'must-be' requirement, which parallels the evolution of e-servicesin a way the future requirements are anticipated [29].

\subsection{Security and perceived risks}

Security is a major concern, as customers are uneasy about entering personal information online. Privacy protection policies may be used to ensure maximum security of personal data 32. Perceived risk is defined as uncertainty about the possible negative consequences of using a product or service 32. Consumers are more comfortable using face-to-face services because they feel that there is less risk 4. This decreases the competitive advantage of e-services and hampers customers' adoption of such services [4]. Featherman and Wells [5] argue that the intangibility of e-services increases the perceived risk as customers cannot visualise or define the e-service. Also, uncertainty of adopting the e-service is increased where customers feel that the system is abstract. According to Featherman and Wells, perceived risk may be classified as follows:

1. Performance risk - The risk of the product malfunctioning

2. Financial risk - The risk of losing money

3. Time risk - The risk of a transaction taking too long to complete

4. Psychological risk-The risk of customer frustration due to using an e-service

5. Social risk-Loss of social status by adopting a particular e-service 
6. Privacy risk-Loss of control over personal information

7. Overall risk-A measurement of perceived risk when all the above risks are evaluated [5]

The categories discussed above play a role in understanding customer needs and strengthening customer relationships. Further research on the factors that influence customer e-service adoption will be beneficial to any organisation as customer satisfaction is an indicator of the sustainability of an organisation. Hence, it is imperative to study the customer's perception of e-services to discover whether it has an impact on customer satisfaction

The South Africa Customer Satisfaction Index is a national rating of the quality of services and products available in South Africa [33. This index is directly linked to customer preferences. The study of the factors that impact customer satisfaction in online shopping can be used to increase the rating of the South African Customer Satisfaction Index. This will attract foreign investment. The acceptance of e-services in South Africa has a dependency on the adoption of ICTs 34. Exposure to international markets has encouraged ICT adoption. This eliminates the geographical barriers for online shopping. It also contributes to the economic growth in South Africa. Given that acceptable ICT is in place, South Africans lean more towards the convenience of using e-services such as e-government 35.

\section{RESEARCH METHODOLOGY}

The aim of this study is to identify and analyse the factors that influence customer e-service adoption, as this knowledge will make a positive contribution to customer services in South Africa. This study will use grounded theory methodology to achieve its main objective - the development of a conceptual framework to show the relationship among, and relative significance of, the factors that influence customer e-service adoption.

\subsection{Research approach: Grounded theory}

The basic idea of grounded theory is to let the theory emerge from the data collection. It involves building a theory rather than testing a theory 36 . Grounded theory has become a popular choice of research methodology in the information systems field 37. Matavire and Brown 36 identified the main principles of grounded theory as emergence, constant comparative analysis and theoretical sampling. Grounded theory methodology was chosen in this study for its comparative process that identifies relationships between categories, and for the fact that it is known to be a flexible method that allows researchers to be innovative 38. These properties make it a suitable choice for gaining a fresh perspective on the factors that significantly affect customer e-service adoption. Grounded theory techniques will be used to build the theory that will show the customers' view of using e-services.
Grounded theory involves the collection of data to build a theory, rather than the introduction of a hypothesis to test a theory 39. According to Egan 38 grounded theory research comprises the following steps: initiation of research, data selection, data collection, data analysis and conclusion of the research. Initiation of research involves the choosing of a topic. Data selection involves identifying or locating sources of data that relate to the research objectives. Data collection involves carrying out interviews, observing participants, and completing surveys. Data analysis involves the categorisation and comparison of the data collected. Conclusion of the research involves providing the results uncovered during the process of the grounded theory research conducted.

Glaser 39 and Strauss and Corbin 40, agree that grounded theory is beneficial to research in any area. This methodology offers the following benefits:

1. Theory derived through data is more likely to resemble reality.

2. The discovery of multiple options for a single phenomenon promotes creative thinking.

3. High interaction with participants leads to more accurate results.

Using this methodology will ensure high interaction with customers and service providers. The emerging theory will contain categories and concepts that focus on this dependency 39. Memos and integrated diagrams will assist in writing up the emerging theory, which is flexible in terms of handling data [40. Grounded theory is useful in gaining a fresh perspective on an area that has been researched previously 41. The emergent nature of the data also makes the data traceable [37. Grounded theory is known as the 'delayed action' phenomenon 39 as findings may emerge after the data has been under analysis for a long while.

Holton's [4] study describes grounded theory as allowing flexibility in the research process, ensuring high quality in the analysis of data and thoroughness. The quality of grounded theory methodology is assessed by the following criteria: fit, work, relevance and modifiability [42. It is critical for categories that emerge to 'fit', 'work' (explain, interpret, and predict) and be relevant for the area of research being studied 43. With modification the core categories must still be relevant [4].

\subsubsection{Philosophical assumptions}

There are three basic approaches to grounded theory research: the Glaserian approach 43, the evolved Straussian approach [40, and the constructivist approach [45. Glaser [46] described the essential methods of grounded theory as follows: initial coding and categorisation of data, concurrent data generation or collection and analysis, writing memos, theoretical sampling, constant comparative analysis using inductive and abductive logic, theoretical sensitivity, intermediate coding, selecting a core category, theoretical saturation and theoretical integration. In studies of the Strauss-Glaser method by Walker and Myrick 47. 
and Devadas et al. 48] many differences were found between Strauss's approach and Glaser's approach:

Paradigmatic differences: The Glaserian perspective favours post-positivism, whereas Strauss focussed on the relationship between the researcher and the research participant. This interactive nature between the researcher and the research participant led to a constructivist view. Post-positivists believe that the researcher's background and knowledge can be useful in determining the research results. Constructivists believe that an individual's experience, preference and background cannot be considered separately from the researched object or study. Individuals create and interpret meanings from the social situations in which they exist and social behaviour which is known. Whereas, positivists believe that the researched object or study should be independent of the researcher's background.

Formulation of research questions: Glaser's approach did not require starting the research with questions. Strauss preferred to enter the field of research with questions.

Use of literature: In both approaches, literature plays an important role in discovering new theory. Glaser objected to using literature at the beginning of the research. He believed that the emerging data would be manipulated by the researcher's preconceptions if literature was used at the beginning of the research. Strauss believed that the use of literature could be implemented at any phase in the research.

Sampling procedures: Both approaches use theoretical sampling. Glaser commented on Strauss's sampling method, stating that Strauss used 'model sampling' which did not allow data to emerge, which is the essence of grounded theory. 'Model sampling' forces the data in an already perceived direction rather than allowing the data to emerge.

Analysis procedures: Both approaches focus on coding and constant comparative methods. The Glaserian approach consists of two phasessubstantive coding (i.e. open and selective coding) and theoretical coding. The Straussian approach consists of three phases - open, axial, and selective coding. The method of constant comparison is central to Glaser's process while the method is embedded in Strauss's approach. Glaser's approach is considered to be more emergent and less 'force to data' as compared to the Straussian approach:

Perhaps, it is simply more a science with

Strauss and more an art with Glaser. 47

Procedures for validating the resulting theory: Glaser's main focus was on the following factors: fit, relevance, work and modifiability. Strauss's focus was more varied, as follows: validity, reliability, credibility, plausibility and value of the theory, adequacy of the research process, and the empirical grounding of the research process.

It may be concluded from the above that Glaser believes in 'true reality' while Strauss preferred 'construc- tive reality' [48. This research favours the constructivist approach. This approach focuses on

first-hand knowledge of empirical worlds, takes a middle ground between postmodernism and positivism and offers methods to improve qualitative research. [45]

Positivism is based on the following premises: knowledge can only be gained from observation and experience; research data must be measurable and objective hence the focus on quantitative data; research begins with models and theories and then defining variables and predicting their relationships and using hypothesis testing 49].

Postmodernism is based on the following premises: rationality, scientific method and the certainties that the modern world no longer holds, there are multiple realities which accept diversity and plurality and are experimental and creative [50]. Constructivists tend to 'describe, understand and interpret' and also to accept 'multiple realities' while being 'context bound' [50]. Constructivists believe that 'individuals seek understanding of the world in which they live and work' and rely heavily on 'participant views' while accepting a 'complexity of views' [51.

Charmaz [52] argues that while quality of grounded theory can be assessed by the criteria: fit, work, relevance and modifiability, it can also be evaluated by credibility, resonance, originality and usefulness. In general constructivists rely on trustworthiness (i.e. credibility, transferability, dependability confirmability) and authenticity (i.e. fairness, increases understanding, promotes action) to ensure rigour [53. It is beyond the scope of this research to debate the veracity of these various approaches (see Lincoln and Guba, 54])

This study places focus on the customer's perception, that is, how the customer interprets the use of e-services in the light of knowledge gained through online shopping. A constructivist approach is feasible for the following reasons: data is allowed to emerge rather than be forced; the inductive approach will allow a fresh perspective on the study, and the coding methods and repetitive comparison lead to more accurate results.

\subsubsection{Development of the conceptual model}

The factors in Table 1 were identified from the researched theory. These factors were the focus areas in previous studies on e-services and online shopping. The factors will be further analysed to determine the relative significance of each factor with regard to the customer's acceptance of e-services.

The categories that form the theoretical framework are input into the research model that will be used to determine the relationship and significance of the factors that affect customer adoption. The aim is to develop a conceptual model that will determine the interrelationships between the factors that influence customer adoption of e-services. 
Table 1: Factors that constitute the theoretical framework

\begin{tabular}{|c|c|}
\hline Delivery performance [2] & $\begin{array}{l}\text { How does the speed of an online system affect customers' perception } \\
\text { of the overall service? }\end{array}$ \\
\hline Elimination of barriers & $\begin{array}{l}\text { Does this create convenience or does it reduce local business? Do } \\
\text { customers prefer to shop online and are they satisfied? }\end{array}$ \\
\hline $\begin{array}{l}\text { Customer trust, loyalty and } \\
\text { social influence } 16 \text { ] }\end{array}$ & $\begin{array}{l}\text { What are the reasons that a customer will return to a particular } \\
\text { e-service? What factors will encourage customers to share their } \\
\text { online shopping experiences? }\end{array}$ \\
\hline Customisation [7] & $\begin{array}{l}\text { What steps should be taken to ensure that customers adopt cus- } \\
\text { tomised e-services? }\end{array}$ \\
\hline Techno-stress [3] & $\begin{array}{l}\text { What impact does techno-stress have on a customer's perception of } \\
\text { e-services? }\end{array}$ \\
\hline $\begin{array}{l}\text { Recovery from system failure } \\
{[7}\end{array}$ & How do customers respond to recovery from failure conditions? \\
\hline Time factor [2] & $\begin{array}{l}\text { Do all e-services satisfy this requirement and how can this be } \\
\text { achieved? }\end{array}$ \\
\hline $\begin{array}{l}\text { User-friendly systems and } \\
\text { customer familiarity [2] }\end{array}$ & $\begin{array}{l}\text { What standard requirements must e-services meet in order to satisfy } \\
\text { customers with varying skills and varying knowledge of e-services? }\end{array}$ \\
\hline Relevant content [2] & How does relevance affect the customer's perception of an e-service? \\
\hline Customer support [2] & $\begin{array}{l}\text { Are online documents sufficient or are call centres the preferred } \\
\text { method of assistance for customers? }\end{array}$ \\
\hline $\begin{array}{l}\text { Satisfying of customer re- } \\
\text { quirements [2] }\end{array}$ & $\begin{array}{l}\text { Did the customer achieve the intended result from the e-service, for } \\
\text { example, was the required product available, was time saved, was } \\
\text { money saved? }\end{array}$ \\
\hline Risk [5] & $\begin{array}{l}\text { How does security risk and perceived risk (performance, financial, } \\
\text { time, psychological, social, privacy) influence customer e-services } \\
\text { adoption? }\end{array}$ \\
\hline
\end{tabular}

\subsubsection{Grounded theory: Process}

The grounded theory research approach is suitable for the development of theoretical frameworks as the methodology possesses the following characteristics 38]: responsiveness aimed at conceptual values and not just the values of the investigator; the ability to fit the situation being researched; and the formation of rigorous theory that emerges from a thorough analysis of contextual data 55. Grounded theory, in interpretative information systems research, is described as traceable to the data and as 'fluid', which means that the emphasis is on the process and the temporal nature of the theory [37. In comparison to ethnography and phenomenology, Grounded theory has been found to have the most promising possibilities for developing a conceptual framework [56]. Theoretical sampling is sampling that is directed by theory. The emerging theory dictates the properties of the sample, for example, the number of participants.

\subsubsection{Data ordering and analysis}

Data ordering involves organising the data in a chronological order according to date and time. This will define the sequence of events which will lead to the identification of categories and concepts [57]. Grounded theory research can produce large volumes of data in the form of recorded interviews, field work, memos and jotted notes [58].

\subsubsection{Theoretical sensitivity}

Theoretical sensitivity is to have insight and the ability to give meaning to data by taking into consideration literature and professional experience [59]. There are two important characteristics for the development of theoretical sensitivity, as discussed by Glaser and Holton:

1. The researcher 'must have the personal and temperamental bent to maintain analytic distance and tolerate confusion and regression while remaining open and trusting to preconscious processing and to conceptual emergence.'

2. The researcher 'must have the ability to conceptualise and organise, make abstract connections, visualise and think multivariately.' 59]

According to Glaser 46] the following aspects will ensure theoretical sensitivity: determine what the data is studying; determine the categories; determine the main concerns of participants and determine the resolutions for the participants' concerns.

\subsubsection{Open coding}

According to Urquhart [57] the aim of this step is to identify concepts and categories from the data collected. This technique was used to identify the core categories based on interviews and surveys pertaining to the online experience of a customer. Patterns in the data will arise and new categories and incidents will emerge [57. 


\subsubsection{Axial coding}

The aim of this process is to associate categories with sub-categories 60. Axial coding will be used to identify the commonalities, differences and trends that exist within the feedback received from the online shoppers.

\subsubsection{Selective coding}

According to Strauss and Corbin [40], in this step core or central categories will be identified. This will ensure that our focus remains on relative categories. The previous two steps - open and axial coding - will provide the researcher with a more focused view of the data and the direction for the research. Only data that supports the research questions should be studied.

\subsubsection{Comparative analysis}

This process involves comparing categories and finding relationships between them. The main objective of the study is to draw relationships between the factors. This will give common meaning to various data categories. According to Matavire and Brown [36], the following can be accomplished by using this technique: ensuring accuracy of data, establishing limits of empirical generalisation, specifying a concept, verifying theory, and building theory.

Glaser and Holton [59] described the process as follows: "Incidents are compared to incidents" to discover uniformity and varying conditions. These become concepts. "The concepts are then compared to more incidents to generate new theoretical properties of the concepts". "The purpose is theoretical elaboration, saturation and verification of concepts, densification of concepts by developing their properties and generation of further concepts. Thereafter, concepts are compared to concepts."

\subsubsection{Memo writing}

According to Glaser [46] the aim of memo writing is to:

- Develop ideas based on the categories.

- Uncover properties of the categories by drawing and filing of analytical properties of the descriptive data.

- Assist in adding order to the constant comparisons of data, incidents, and categories.

- Direct the theoretical sampling and identify gaps that may exist in the data analysis.

\subsection{Validity and reliability}

According to Flint et al. 61, grounded theory lacks a concise measure for validity. The criteria proposed by Charmaz [52] is leveraged to test the validity of the study undertaken. Strauss and Corbin [40] considered Charmaz's criteria as being 'comprehensive', 'creative' and 'scientific'. The criteria proposed by Charmaz [52] is a set of questions based on four facets: originality, credibility, resonance and usefulness. Originality is about ensuring that there are new insights offered. Credibility is about immersion in the research data and providing sufficient evidence for the research claims. Resonance involves establishing a shared understanding among relevant stakeholders. Usefulness is essentially about ensuring that analysis has practical application.

Although using Charmaz's criterion is sufficient for establishing validity, for the purposes of ensuring rigour the standard process of establishing in qualitative studies which is trustworthiness is also considered. Trustworthiness is a parallel term for validity in quantitative studies and many of the standard procedures for trustworthiness in qualitative studies are built into grounded theory [62]. These procedures include: triangulation, searching for 'disconfirming evidence', 'member checking', using 'thick, rich description', leaving an 'audit trail', 'disconfirming evidence' (i.e. negative case analysis), 'prolonged engagement in the field' and 'thick, rich descriptions' 53. Trustworthiness is established by credibility, transferability, dependability and confirmability and are mapped to the positivistic notions of internal validity, external validity, reliability and objectivity respectively [54].

Sikolia et al. 63. mapped Lincoln and Guba's 54 proposal and their procedures for establishing trustworthiness into an evaluative framework for grounded theory:

- Credibility as 'how much the data collected accurately reflects the multiple realities of the phenomenon.' which relates to internal validity

- Transferability as 'the applicability of one set of findings to another setting' which relates to external validity

- Dependability as "the confirmation that the data represents the changing conditions of the phenomenon.' which relates to reliability.

- Confirmability as 'if another researcher confirms the findings if presented with the same data.' This relates to objectivity

The criteria proposed by Charmaz [52] and Sikolia et al. 63] is leveraged to confirm the validity and reliability of the study and is undertaken in Section 9.

\subsection{Sampling method}

Participants from an IT division of an organisation, within Gauteng, were surveyed. Participants were selected according to age, employment in an IT profession, and their level of e-Service exposure. IT is responsible for ensuring effective delivery of IT systems and processes to support the organisation's objectives. These categories of age, profession and e-service exposure were intended to give an indication of the experience the participant has with online services, the participants' familiarity with technology, and how accessible e-services are to the participants. There were 60 participants in total and random sampling was used. 


\section{DATA COLLECTION}

The following methods were used to collect data:

1. Semi-structured interviews (Appendix A): These questions provided a high-level view of the users' experiences. The questions were derived by considering the factors in the literature review.

2. Observation

3. Qualitative surveys which were distributed via e-mail (Appendix B). These questions aimed to provide an in-depth understanding of the users' experiences. The questions were derived from online shopping studies [2, 3, 64, 65]. The questions were modified to relate to the study of customer e-service adoption.

Participants were classified into groups depending on age, experience using technology and available access to e-services. The aim was to encourage interaction and discussion based on commonality amongst the participants. This allowed new data to emerge as shown in Table 2 and Fig. 1.

Table 2: Participant groupings

\begin{tabular}{|l|l|l|l|}
\hline & Age range & Description & Method \\
\hline Group 1 & $21-25$ years & IT professionals & 1 and 3 \\
Group 2 & $21-25$ years & Novice users & 1 and 3 \\
Group 3 & $21-25$ years & IT professionals & 1 and 2 \\
Group 4 & $21-25$ years & Novice users & 1 and 2 \\
Group 5 & $26-50$ years & IT professionals & 1 and 2 \\
Group 6 & $26-50$ years & Novice users & 1 and 2 \\
Group 7 & $26-50$ years & IT professionals & 1 and 3 \\
\hline
\end{tabular}

The classification of participants influenced the research significantly. For example, the valuation of the data showed the following:

1. A larger percentage of participants between the ages of 21 and 25 preferred e-services.

2. The fear of risk was evident across the research population showing that age, level of IT experience and easy access to e-services was an independent factor.

3. More techno-stress was experienced in the age groups of 26-50 where participants had little technology experience.

The e-services used in the study were according to the users' preferences. The interview questions were aimed at understanding the customers' perception of the use of e-services. In this study the interview consisted of structured questions, semi-structured questions and observation. The observation involved viewing the customer navigating an online purchase. The observations focussed on the following:

1. The sequence of actions.

2. Identifying the ease and comfort level of navigation.

3. The preferences and products purchased.

4. The challenges experienced and the resolutions that followed.

5. The finalisation of the transaction.
Memos and diagrams were also used to record and compare ideas and concepts. By writing memos, the relationships between codes and theory were identified. Diagrams help in the visualisation of the relationships between categories.

\section{DATA ANALYSIS}

The results of the survey were analysed using the NVivo tool. NVivo is software that can easily organise and analyse unstructured information. The analysis involved considering each category identified and the interrelationships that were discovered between these categories are listed in Table 1 . The surveys are available

\subsection{Delivery performance}

All participants indicated that this was a major factor in using online services. All participants valued services that saved them time. Delivery performance was directly linked to the following categories: customer trust, loyalty and social influence, techno-stress, recovery from system failure, time factor and risk. A further explanation is provided below:

1. Customer trust: Shorter system response times led to greater customer trust with $15 \%$ of participants stating that they would return to an e-service because they had saved time due to excellent system response time.

2. Techno-stress: Shorter system response times led to a decrease in techno-stress. Participant \#3 responded to question 7: "I enjoyed my shopping experience as the response to every button was immediate. This was pleasing and less frustrating".

3. Recovery from system failure: Shorter system response times led to shorter times for the system to recover from failure. Participant \#10 responded to question 8: "The error I came across was resolved efficiently which made me complete my shopping with hardly any hassle".

4. Time factor: Shorter system response times led to decreases in the time taken to complete a purchase.

5. Risk: Shorter system response times led to a decrease in the performance risk perception.

\subsection{Elimination of barriers}

Elimination of barriers accounted for $10 \%$ of the research population indicating that they preferred online services as they did not have to leave their homes or offices to make a purchase. They also expressed that the preference for shopping online is linked to the availability of a variety of products. That is, products not otherwise available in South Africa can be purchased. This also leads to an inflow of foreign exchange as people not living in South Africa can purchase South

\footnotetext{
${ }^{1}$ https://sites.google.com/site/keshneepadayachee/ResearchProjects/kamisha-persad
} 


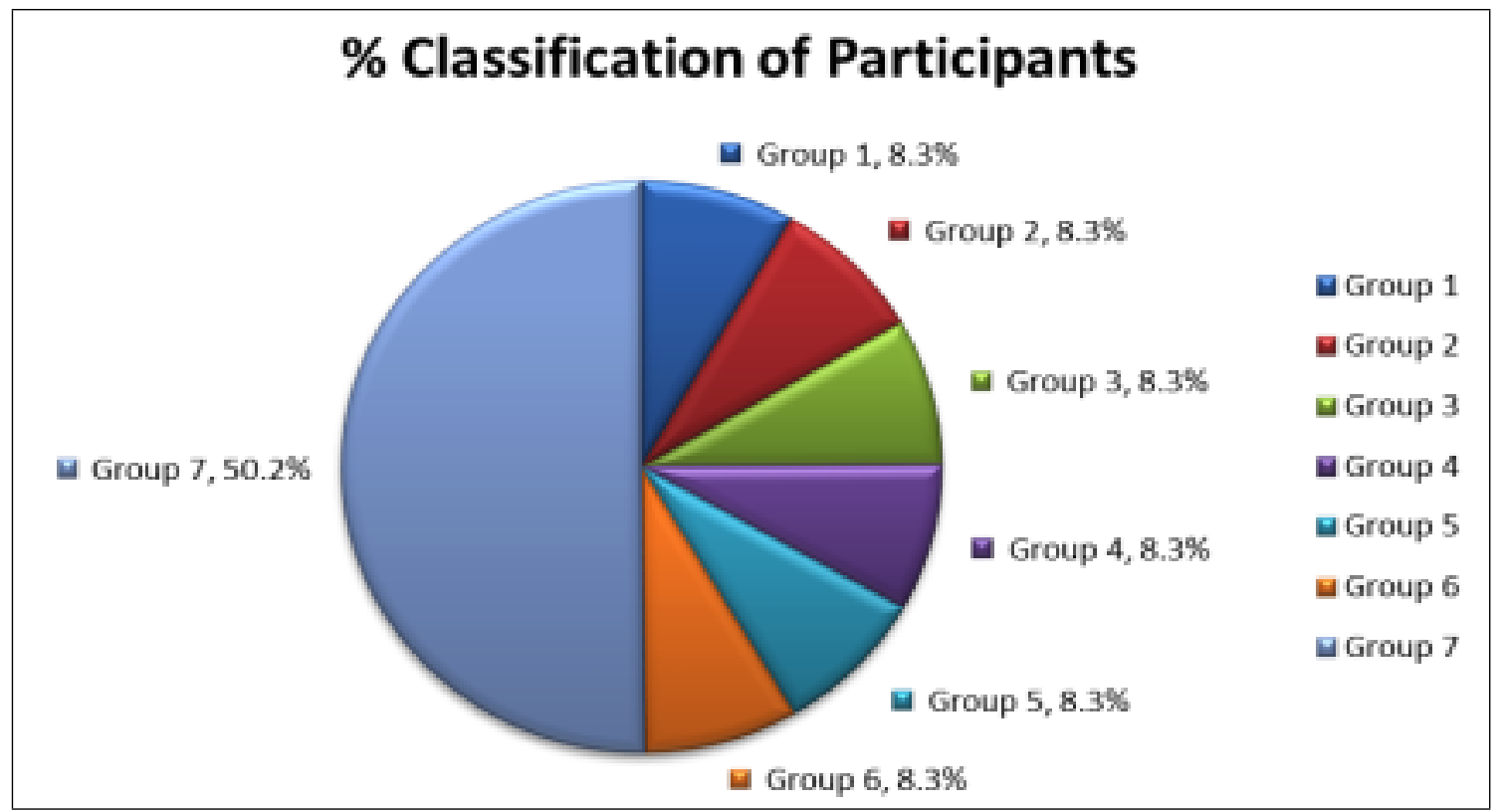

Figure 1: Classification of participants

African products using e-services. Elimination of barriers was directly linked to the following categories: the time factor, satisfying customer requirements, and risk. The elimination of barriers factor was correlated with the following factors which foster customer e-service adoption:

1. Time factor: The time taken to complete the purchase online and the delivery time was acceptable to $70 \%$ of the participants. Participant \#5 responded to question 14: "saving time is very important to my busy lifestyle".

2. Satisfying customer requirements: Eliminating geographic barriers increased the variety of products available. Participant \#2 responded to question 12: "I do not have to spend money on an overseas holiday to find the brand I like".

However elimination of barriers was negatively correlated with the financial risk factor which inhibits customer e-services adoption. It was discovered that participants were more cautious when using international e-services and expressed more concern regarding their financial details. Participant \#4 responded to question 17: "I'm not too confident about shopping in other currencies and having things delivered to me from other countries".

\subsection{Customer trust, loyalty and social influence}

Customers will trust an e-service and return to it if their experience was satisfactory. The analysis showed that $70 \%$ of the research population trusted e-services and will return to the e-service chosen. The remaining $30 \%$ indicated that fraud, identity theft and financial loss contributed to their mistrust of e-services.

Customer trust, loyalty and social influence were directly linked to the following categories: delivery performance, customisation, techno-stress, user-friendly systems and customer familiarity, relevant content, customer support, satisfying of customer requirements, and risk. This factor was correlated with the following factors, which foster customer e-service adoption:

1. Delivery performance: Shorter system response times led to greater customer trust.

2. Customisation: The e-services which take users considerations and suggestions into account increased customer trust. Participant \#1 responded to question 12: "Any service that cares about what I need is a good service provider. I will continue shopping online".

3. Techno-stress: A decrease in techno-stress led to an increase in customer trust. Participant \#32 responded to question 13: "Even though I had to re-log in [sic] because of Internet problems, I was still able to buy my goodies with ease".

4. User-friendly systems: User-friendly systems increased customer trust.

5. Relevant content allowed the users to make good decisions regarding their purchases. This increased customer trust.

6. Customer support: All participants in the research population preferred call centre support. Users who received efficient online support became loyal customers of that e-service. Efficient customer support increased customer trust and loyalty.

7. Satisfying of customer requirements: Participants were satisfied if the product they intended to purchase was available.

The customer trust, loyalty and social influence factor was negatively correlated with the privacy risk factor which inhibits customer e-service adoption. Participants were comfortable with e-services that requested more than one password, additional access details, and provided safe transacting methods. A decrease in privacy risk led to an increase in customer trust and loyalty. Participant \#53 responded to question 23: "I don't shop on the Internet because I do not know how strong the security methods are". 


\subsection{Customisation}

All participants agreed that an e-service that heeds the requests of customers is an e-service that they would use. Customisation was directly linked to the following categories: customer trust, loyalty and social influence, techno-stress, the time factor, user-friendly systems and customer familiarity, relevant content, satisfying of customer requirements, and risk. The customisation factor was correlated with the following factors, which foster customer e-service adoption:

1. Customisation increased customer trust, loyalty and social influence.

2. Techno-stress: Participants who suggested ways to make an e-service user-friendly explained that their intent was to reduce techno-stress. An increase in customisation led to a decrease in technostress.

3. Time factor: Customisation provides the customer with exactly the right tools to assist with his or her purchase online. This reduces the time taken to make a purchase.

4. User-friendly systems and customer familiarity: Participants explained that customisation requirements were to improve the e-service from a customer's perspective. The intent was to increase the ease in using the e-service. Participant \#6 responded to question 2: "English is not my first language so I use this site because the language is simple and to the point".

5. Relevant content: Participants suggested the type of content that should be available online. By allowing this sort of customisation, the e-service added more value to the participant's shopping experience. As a result, the participant was not overwhelmed by unnecessary or too much information. Participant \#8 responded to question 6 : "I don't have to battle with last year's prices vs this year's inflated costs".

6. Satisfying of customer requirements: Customisation requests aim to provide customers with exactly what they need and/or want.

However, the customisation factor was negatively correlated with the financial risk factor which inhibits customer e-services adoption. Participants perceived customisation as being costly. There was concern that the prices of products would increase to compensate for the customisation cost.

\subsection{Techno-stress}

Techno-stress occurs when customers cannot cope with the fast-changing technology [3]. This was experienced mostly in groups 6 and 7 . These groups included participants who did not have experience with technology, nor did they have easy access to the Internet. Technostress was directly linked to the following categories: delivery performance, customer trust, loyalty and social influence, customisation, recovery from system failure, the time factor, user-friendly systems and customer familiarity, relevant content, customer support, satisfying of customer requirements, and risk. The techno-stress factor was correlated with the following factors, which foster customer e-service adoption:

1. Delivery performance: Shorter system response times led to a decrease in techno-stress. Participant \#7 responded to question 7: "I don't want to spend more time than I have to. I don't want to give hackers time to work their misdeeds".

2. Customer trust, loyalty, and social influence: A decrease in techno-stress led to an increase in customer trust.

3. Customisation: Participants who suggested ways to make an e-service user-friendly explained that their intent was to reduce techno-stress. An increase in customisation led to a decrease in technostress.

4. User-friendly systems and customer familiarity: $75 \%$ of participants selected online services that they were familiar with and that were easy to use. The more user-friendly a system was, the less techno-stress was experienced.

5. Relevant content: Participants indicated that relevant content decreased techno-stress.

6. Customer support: Participants preferred shopping on websites that had valid contact details, for example, a valid telephone number for inquiries or product/system problems. The more options there were for customer support, the less technostress was experienced.

7. Satisfying customer requirements: Participants stated that reducing techno-stress should be a requirement for all e-services. If this requirement is satisfied then there will be more online shoppers. A decrease in techno-stress implied to participants that customer requirements were being met.

The techno-stress factor was correlated with the following factors which inhibit customer e-service adoption: recovery from system failure, time and financial risk. Errors and system failures created confusion, frustration and dissatisfaction with participants. There were errors where clicking on objects did not give the intended result or where there was no response from the system. The longer the system took to return to a functional state, the more techno-stress was experienced. Techno-stress in respect of the risk of fraud was experienced by $25 \%$ of participants when the eservice crashed. Under these circumstances, there was an increase in frustration levels due to participants not knowing if the purchase was complete or not. Passwords and confirmation messages decreased techno-stress and also decreased concerns about privacy risk. Techno-stress was experienced by $25 \%$ of the participants when time was wasted on trying to decipher errors and find online help.

\subsection{Recovery from system failure}

Recovery from system failure is necessary when an e-services system crashes or suffers errors that prevent the participant from completing his or her purchase. This was experienced by $25 \%$ of the participants. Recovery from system failure was directly linked to the following categories: delivery performance, techno-stress, 
the time factor, user-friendly systems and familiarity, customer support, and risk. This factor was correlated with the following factors, which foster customer e-service adoption:

1. Delivery performance: Shorter system response times led to shorter times being needed for the system to recover from failure.

2. Time factor: All participants agreed that the purpose of e-services is to save time and cost. The shorter the time taken by the system to recover, the more satisfied participants were.

3. User-friendly system and familiarity: User-friendly systems allowed participants to resolve problems very quickly and complete their purchases. Participants who were familiar with the e-service chosen were also able to identify the problem very quickly and obtain customer support. Recovery from system failure takes less time where the system is easy to use, that is, user friendly.

4. Customer support: An increase in efficient customer support led to a decrease in system recovery time. Participant \#9 responded to question 16: "When I go into a shop I can literally speak to a person but this is not possible on the websites. I depend on the online help links to replace the person that I would usually deal with. I have no complaint [sic] about the help that I got online". The recovery from failure factor was correlated with the techno-stress and financial risk factors, both of which inhibit customer e-service adoption. The longer a system took to return to its functional state, the more techno-stress was experienced. Participants expressed concern regarding the risk of capturing financial details online where this might be followed by a system fault. Novice participants often indicated that they were uncomfortable because they were unsure if the details were saved online or not. It was discovered that the shorter the time taken to recover from a system fault, the more comfortable participants felt about transacting online and that this favoured e-service adoption.

\subsection{Time factor}

The time factor was directly linked to the following categories: delivery performance, customisation, technostress, recovery from system failure, user-friendly system and familiarity, relevant content, customer support, satisfying of customer requirements, and risk. $70 \%$ of the research population indicated that time was saved by shopping online. The time factor was correlated with the following factors, which foster customer e-service adoption:

1. Delivery performance: Shorter system response times led to a decrease in the time taken to complete a purchase.

2. Customisation: Customisation led to a decrease in the time taken to complete a purchase.

3. Recovery from system failure: All participants agreed that the purpose of e-services is to save time and cost. The shorter the time taken by the system to recover, the more satisfied participants were.
4. User-friendly system and familiarity: It was discovered that the more user-friendly the system and more familiar it is to the participant, the less time is taken to complete a purchase.

5. Relevant content: Relevant content allowed for decisiveness in the completing of purchases and also reduced the time factor. Participant \#56 responded to question 12: "I cannot do without the search option. This saves me so much time because I can put in my requirements I the advanced search option to bypass information that I have no interest for [sic]".

6. Customer support: It was discovered that efficient customer support decreased the time factor.

7. Customer requirements: In $70 \%$ of the cases studied, the customer was satisfied because his or her requirements were met. The participant could complete his or her purchase within an acceptable time. Meeting all the customers' requirements led to a decrease in online shopping time.

8. Techno-stress: $25 \%$ of participants spent more time trying to decipher errors compared to participants that were familiar with using e-services. This increased techno-stress. E-service adoption is favoured where there is a decrease in technostress which, in turn, decreases the time taken to complete a purchase.

9. Risk: Time risk is decreased in e-service adoption because the participant's perception is that the purpose of e-services is to save time.

\subsection{User-friendly systems and customer familiarity}

Customers who use e-services have varying levels of knowledge of technology. It was discovered that colours, pictures chosen for icons, confirmation messages, text size, menu content, and online documents and videos all contributed to making a system user-friendly. Only $1 \%$ of the research population chose a service that they were not familiar with. User-friendly systems and customer familiarity were directly linked to the following categories: customer trust, loyalty and social influence, customisation, techno-stress, recovery from system failure, time factor, customer support, satisfying of customer requirements and risk. The userfriendliness factor was correlated with the following factors, which foster customer e-service adoption:

1. Customer trust, loyalty and social influence: Userfriendly systems increased customer trust.

2. Customisation: Taking the participants suggestions for improvement into consideration led to customisation. This led to easy use of systems.

3. Techno-stress: $99 \%$ of participants selected online services that they were familiar with and that were easy to use. The more user-friendly a system was, the less techno-stress was experienced.

4. Recovery from system failure: User-friendly systems allowed participants to resolve problems and complete their purchases very quickly. Participants who were familiar with the e-service chosen 
were also able to identify the problem and obtain customer support very quickly.

5. Time factor: It was discovered that the more user-friendly the system and the more familiar to the participant it was, the less time was taken to complete a purchase.

6. Customer support: One of the factors that participants used to measure the level of user-friendliness of a system was the efficiency and availability of customer support. An increase in efficient and available customer support led to an increase in the perceived user-friendliness of the system.

7. Satisfying of customer requirements: A system classified as user-friendly implied to participants that user requirements were being met. An increase in user-friendly functionality also led to an increase in customer requirements being satisfied. Participant \#51 responded to question 1: "If the site can provide for my needs and purpose then I will definitely shop on the Internet".

The user-friendliness factor was correlated with the financial risk and privacy risk factors that inhibit customer e-service adoption: with respect to financial risk, $11 \%$ of the research population stated that risk of fraud and identity theft (i.e. privacy risk) was low in popular websites. The same $11 \%$ also felt safer using the e-service knowing that thousands of other people preferred that particular e-service.

\subsection{Relevant content}

The importance of relevant content is to allow customers to make the correct choice when shopping online. Relevant content was directly linked to the following categories: customer trust, loyalty and social influence, customisation, techno-stress, the time factor, customer support, satisfying of customer requirements, and risk. The relevant content factor was correlated with the following factors, which foster customer eservice adoption:

1. Customer trust, loyalty and social influence: Relevant content allowed the users to make good decisions regarding their purchases. This increased customer trust.

2. Customisation: Participants suggested the type of content that should be available online. By allowing them to do so, the e-service added more value to the participant's shopping experience. The participant was not overwhelmed by unnecessary information.

3. Time factor: Relevant content allowed decisiveness in completing purchases. Relevant content reduces the time factor. Participant \#47 responded to question 12: "If the service provider can save me time by showing me only the information I need, then I will use that e-service".

4. Customer support: Participants stated that customer support is dependent on relevant and accurate contact details. Relevant content increased the quality of customer support.
5. Satisfying of customer requirements: $78 \%$ of the research population experienced customer satisfaction due to relevant content. Participants indicated that relevant content is a factor that satisfies customer requirements.

6. Risk: $22 \%$ of the research population experienced the psychological risk of not receiving the correct product or bill. This was related to irrelevant, incorrect and outdated content. Relevant content may reduce the risk of receiving the incorrect products.

7. Techno-stress: Participants indicated that relevant content decreased techno-stress.

\subsection{Customer support}

Customer support was directly linked to the following categories: customer trust, loyalty and social influence, techno-stress, recovery from system failure, the time factor, user-friendly systems and familiarity, relevant content, satisfying of customer requirements, and risk. The customer support factor was correlated with the following factors, which foster customer e-service adoption:

1. Customer trust, loyalty and social influence: $100 \%$ of the research population preferred call centre support. Users who received efficient online support became loyal customers to that e-service. Efficient customer support increased customer trust and loyalty. Participant \#45 responded to question 23: "Telephone help is more effective than emails. The sites I use have given me efficient help telephonically. This is as good as physically [sic] assistance over the counter".

2. Recovery from system failure: An increase in efficient customer support led to a decrease in system recovery time.

3. Time factor: It was discovered that efficient customer support decreased the time factor.

4. User-friendly systems and familiarity: One of the factors that participants used to measure the level of user-friendliness of a system was the efficiency and availability of customer support. An increase in efficient and available customer support led to an increase in the perception of user-friendliness.

5. Relevant content: Participants stated that customer support is dependent on relevant and accurate contact details. Relevant content increased the quality of customer support.

6. Satisfying of customer requirements: All participants agreed that online customer support is mandatory. $75 \%$ of the research population indicated that their requirements were met due to efficient online customer support. E-service adoption is favoured where efficient customer service, that satisfies customer requirements for online shopping, is available.

The customer support factor was negatively correlated with the risk and Techno-stress factors, which inhibit customer e-service adoption. With regard to risk, 25\% 
of the research population expressed concerns regarding the risk of no online support. It was discovered that, without online support, customers would rather drive to a physical shopping centre. Risk is decreased where efficient online support is available. This relationship favours e-service adoption. Participants preferred shopping on websites that had valid contact details, for example, a valid telephone number for inquiries or product/system problems. The more options that were available for customer support, the lower the level of techno-stress that was experienced.

\subsection{Satisfying of customer requirements}

Satisfying of customer requirements was directly linked to the following categories: elimination of barriers, customer trust, loyalty and social influence, customisation, techno-stress, the time factor, user-friendly systems and familiarity, relevant content, customer support, and risk. The satisfying customer requirements factor was correlated with the following factors, which foster customer e-service adoption:

1. Elimination of barriers: Eliminating geographic barriers increased the variety of products. Participant \#44 responded to question 12: "I want variety and unlimited options from the comfort of my home".

2. Customer trust, loyalty and social influence: Participants were satisfied if the product they intended to purchase was available.

3. Customisation: Allowing for customisation requests is aimed at providing customers with exactly what they need/want.

4. Time factor: In $70 \%$ of the cases studied, the customer was satisfied because his or her requirements were met. The participant could complete his or her purchase within an acceptable time. Meeting all the customer's requirements led to a decrease in online shopping time.

5. User-friendly systems and familiarity: A system classified as user-friendly implied to participants that user requirements were being met. An increase in user-friendly functionality led to an increase in satisfying of customer requirements.

6. Relevant content: $78 \%$ of the research population experienced customer satisfaction due to relevant content. E-service adoption was favoured where relevant content existed to satisfy the customers' shopping requirements.

7. Customer support: All participants agreed that online customer support is mandatory. $75 \%$ of the research population indicated that their requirements were met due to efficient online customer support. E-service adoption is favoured where efficient customer service is available and where it satisfies customer requirements for online shopping.

The satisfying customer requirements factor was negatively correlated with techno-stress, which inhibits customer e-service adoption. Participants stated that reducing techno-stress should be a requirement for all eservices. If this requirement is satisfied then there will be more online shoppers. A decrease in techno-stress implied to participants that customer requirements were being met. The satisfying customer requirements factor was negatively correlated with risk and this inhibits customer e-service adoption. Participants agreed that e-services that cannot satisfy basic requirements, such as, strong and reliable options for secure transacting, a variety of products, efficient online support and user-friendly functionality, are at risk (i.e. social risk) of losing both credibility and customers. Satisfying customer needs leads to less risk of losing customer trust and loyalty which, in turn, increases e-service adoption.

\subsection{Risk}

Security risks occur when personal data is misused (Rust, Kannan 2003). Perceived risk is measured according to the following categories: performance, financial, time, psychological, social, and privacy risk 4]. A further explanation of the abovementioned risks is found in Section 2.10. Risk affects customer satisfaction and this, in turn, has an impact on the increase/decrease in customer e-service adoption. 100\% of the research participants mentioned risk. Risk was directly linked to all categories, that is: delivery performance, elimination of barriers, customer trust, loyalty and social influence, customisation, techno-stress, recovery from system failure, time factor, user-friendly systems and familiarity, relevant content, customer support, and satisfying of customer requirements. The risk factor was correlated with the following factors, which foster customer e-service adoption:

1. Delivery performance: Shorter system response times led to a decrease in the risk of having the system fail while personal and financial details were being entered. This relates to time risk.

2. Customer trust, loyalty and social influence: Participants were comfortable with e-services that requested more than one password, additional access details, and provided safe transacting methods. A decrease in risk led to an increase in customer trust and loyalty. This relates to privacy risk.

3. Recovery from system failure: It was discovered that the shorter the time taken to recover from a system fault, the more comfortable participants felt about transacting online. This relates to time risk.

4. User-friendly systems and familiarity: $11 \%$ of the research population stated that risk of fraud and identity theft was low in popular websites. The same $11 \%$ also felt safer using the e-service knowing that thousands of other people preferred the same e-service. This relates to social and privacy risk.

The risk factor was correlated with the following factors which inhibit customer e-service adoption:

1. Customer support: $25 \%$ of the research population expressed concerns regarding the risk of no 
online support. This relates to time, financial and psychological risk.

2. Customer requirements: Participants agreed that e-services that cannot satisfy basic requirements, such as, strong and reliable options for secure transacting, variety of products, efficient online support and user-friendly functionality, are at risk of losing both credibility and customers. This relates to psychological risk.

3. Relevant content: $22 \%$ of the research population experienced the risk of receiving irrelevant, incorrect and outdated content. This relates to performance and financial risk.

4. Time factor: An increase in the time factor led to a decrease in new and existing e-service users. This relates to time risk.

5. Elimination of barriers: Participants were more cautious when using international e-services. There was more concern regarding financial details. This relates to privacy risk

6. Customisation: Participants perceived customisation as being costly. This relates to financial risk.

7. Techno-stress: $25 \%$ of participants experienced techno-stress relating to risk of fraud when the eservice crashed. Participants were concerned that their banking details would be misused. There was an increased level of frustration regarding not knowing if the purchase was complete or not. This relates to privacy and psychological risk. Participant \#37 responded to question 21: "I will not shop on the Internet. There are too many opportunities for risk and loss of money and personal information".

Table 3 summarises the percentage of users that had a positive/negative experience in relation to each category.

Table 3: Summary of user experience

\begin{tabular}{|l|r|r|}
\hline Category name & Positive & Negative \\
\hline Delivery performance & $70 \%$ & $30 \%$ \\
Elimination of barriers & $90 \%$ & $10 \%$ \\
Customer trust, loyalty and & $70 \%$ & $30 \%$ \\
social influence & $100 \%$ & \\
Customisation & $75 \%$ & $25 \%$ \\
Techno-stress & $75 \%$ & $25 \%$ \\
Recovery from system fail- & & \\
ure & $70 \%$ & $30 \%$ \\
Time factor & $99 \%$ & $1 \%$ \\
User-friendly system and & & \\
customer familiarity & $78 \%$ & $22 \%$ \\
Relevant content & $100 \%$ & $0 \%$ \\
Customer support & $70 \%$ & $30 \%$ \\
Satisfying of customer re- & & \\
quirements & $70 \%$ & $30 \%$ \\
Risk & & \\
\hline
\end{tabular}

\subsection{New categories}

During the analysis, new categories emerged from the data. These categories are discussed below.

\subsection{Foreign exchange}

Business is not only about creating a product that can be sold. It is about customer satisfaction related to the product and creating a competitive advantage [31. $10 \%$ of participants stated that e-services attract the inflow of foreign exchange into South Africa by making South African products available abroad. Evidently, an increase in the use and improvement of e-services led to an increase in foreign investment. Foreign investment has a link to the category elimination of barriers.

\subsection{Spontaneous delight}

Spontaneous delight is where a customer is offered a surprise reward [7]. Participants who received surprise gifts or unexpected discounted prices expressed customer satisfaction. $10 \%$ of the research population experienced customer satisfaction due to spontaneous delight. Evidently, spontaneous delight is linked to customer loyalty as participants were willing to return to the e-services that provided the surprise reward. An increase in spontaneous delight led to an increase in customer satisfaction and loyalty, which led to e-service adoption.

\subsection{Preference to popular/well-known e-services}

It was discovered that users trusted popular e-services that attracted large numbers of customers. This was the view of $11 \%$ of the research population. It was discovered that the more popular the e-service, the greater the acceptance of that e-service. The overall analysis of the data showed that $70 \%$ of the research population preferred using e-services, while $30 \%$ of the population preferred face-to-face services. These results have taken all the above-mentioned categories into consideration. The aim of the study was to determine the factors that contribute to e-service adoption. The intention was to develop a conceptual framework that represents the interrelationships between the factors that contribute to e-service adoption/rejection.

Table 4 indicates the percentage of users that commented on the new/uncovered categories.

Table 4: Summary of user experience to new categories

\begin{tabular}{|l|r|}
\hline Category name & Percentage \\
\hline Foreign exchange & $10 \%$ \\
Spontaneous delight & $10 \%$ \\
Preference to popular e-services & $11 \%$ \\
\hline
\end{tabular}

\section{DISCUSSION OF FINDINGS}

The data was collected using a mixed method approach to ensure reliability and validity. The classification 
of participants influenced the research significantly. For example, the valuation of the data showed the following:

- A larger percentage of participants between the ages of 21 and 25 preferred e-services. A reason for this observation is that this age group is more technology savvy and known as the technology generation.

- The fear of risk was evident across the research population showing that age, level of IT experience and easy access to e-services was an independent factor. The older generation feared risk the most. This was also the generation that was greatly impacted by techno-stress. This showed that advancement in technology is not widely accepted by the older generation. Online trust issues also arise in the older generation who prefer face-to-face interaction.

- More techno-stress was experienced in the age groups of 26-50 where participants had little technology experience.

The aim of the data collection and analysis was to discover the factors that impact customer e-service adoption. The literature review provided a view of the existing factors. The results of the analysis above are in line with the discoveries made in previous studies. New categories were also discovered from this study. Answers to the following research questions were derived from this study.

1. What are the factors that enable e-service adoption? These are the factors that encourage customers to use e-services. These factors were: increased e-service delivery performance, reduced time to complete a purchase, elimination of barriers, increased trust, loyalty and social influence; increased customisation, minimal time to recover from system failure, user-friendly system, relevant content, online customer support, foreign exchange, spontaneous delight, preference to popular e-services, and meeting customer needs.

2. What are the factors that inhibit e-service adoption? These are the factors that lead to the rejection of e-services. These factors were: technostress and perceived risk.

3. How does perceived risk affect e-service adoption by the customer? There are different types of risks. These are performance, financial, time, psychological, social, and privacy. Perceived risk refers to the overall risk. All surveys indicate that risk is a concern to customers. Risks discourage customers from shopping online.

4. What is the relationship between a customer's perception of an e-service and the enablers and inhibitors of e-service adoption? The survey responses showed that the enabling factors motivate customers to take advantage of the efficiency and convenience of e-services. However, the inhibiting factors discourage the acceptance of e-services. Customers are afraid of losing money or time and of purchasing poor quality products.
Collier and Bienstock 64 studied the importance of customer satisfaction in e-Retailing. The results showed that the customer's perception of e-services determines whether a customer will return to a particular e-service. The design, information accuracy, privacy, functionality, and the usability of a web site could bias a customer's perception of quality in the future. This is similar to the results presented in this paper regarding customer trust and loyalty. Both studies also focus on the importance of meeting the customer's requirements in order to ensure customer e-service adoption.

Tarafdar et al. [3] studied the impact of technostress on end-user satisfaction and performance. The results obtained are consistent with the Tarafdar et al. 3] study, that is, techno-stress failed to ensure customer e-service adoption. In this study techno-stress was shown to influence satisfying customer requirements and also influences a customer's perception of usability and system familiarity. Customer familiarity promotes customer e-service adoption as the customer feels comfortable and confident to use the e-service.

Park and Kim 65. found that 'information quality, user interface quality, and security perceptions' are significantly related to e-services adoption. This study also found that user friendly systems impact satisfying customer requirements. Relevant content influences customer loyalty. It is also found that all types of risk including security risk influence all factors in e-services adoption.

Lee and Joshi [2] found that the relative importance of different factors in e-services for customer satisfaction were these factors (in order of importance): delivery performance, time saved, website functional properties, Internet familiarity, and price saved. Conversely, website aesthetic properties, risk, customer support, and product variety were least significant. In this study, the issues of delivery performance and time taken to recovery from failure contributed to technostress which explains why Lee and Joshi's study found these factors were significant factors towards customer satisfaction. In this study it was found that customisation and satisfying customer requirements influenced the perception of a user friendly system and familiarity. Lee and Joshi found that customer support was less significant while the current study showed that this factor influences the perception of usability, techno-stress, customer trust, loyalty and social influence, satisfying of customer needs, time to recover from failure, relevant content, and the time factor. Hence this factor influences the perception of other significant factors such as performance. While the current study showed that risk was relevant to all factors and is consequently highly significant.

\section{THE PROPOSED FRAMEWORK}

Grounded theory consists of four steps to evaluate raw data. These steps are open coding, axial coding, selective coding and comparative analysis. These four steps combined with memo writing and the use of the Nvivo analysis tool transformed raw data into 
meaningful information.

The semi-structured interview focused on the positive and negative factors that impact online shopping. A negative factor that was prevalent in all responses was the risk factor. This factor was placed separately from the list of negative factors. The list of responses from participants provided a high level view of their preference to shop online. A further analysis of the qualitative survey resulted in identifying the factors that influence e-service adoption/rejection.

Open coding involved capturing memos on NVivo. These were ideas, focal points, or responses on which participants placed emphasis. The focal points, from the survey, were: speed of the online service, being able to shop from home, customer trust, modifications to suite the customer's needs, fewer frustrations, fewer system errors, easy to use sites, important information, online help, customer satisfaction and loss. These focal points were re-phrased as follows: delivery performance, elimination of barriers, customer trust, customisation, techno-stress, recovery from system failure, time factor, user friendly, relevant content, customer support, satisfying of customer requirements and risk.

In axial coding, it became clear that the participants focused on four specific areas. These areas were human emotions, perception of the physical websites, questioning the need to shop online and the risk of online shopping. Four main categories were discovered. These categories were need for purpose, system functionality, customer attitude and risk. The factors identified in open coding were grouped within these categories. The evaluation tool then flagged each factor depending on whether the participant referred to the factor as having improved his/her shopping experience or not. Green represented a positive contributor to online shopping. Red indicated a negative contributor to online shopping. The green and red indicators were converted into a percentage format, eventually showing that $70 \%$ of the participants enjoyed shopping online, while $30 \%$ of participants preferred face-to-face interaction.

The process of selective coding is used to eliminate categories that are not relevant to the research. The evaluation tool has a cross-examination function which searches all participants' responses. It then creates a list of common responses verses the exceptions. It also displays the trends in the data collected. Three exceptions were identified. These were foreign exchange, spontaneous delight and preference to popular e-services. All factors, categories and exceptions proved to be relevant to the research.

During comparative analysis, the memos and graphs created by the evaluation tool were extensively used. The graphs showed the impact of each factor on another. These are explained by Fig. 3, 4 and 5 . Each category represented a parent node. Each factor represented a child node. Each connecting line represented a positive or negative impact on online shopping, in accordance with the participants' responses. The evaluation tool highlighted the duplicate links or common paths between parent and child nodes, parent and parent nodes, and child and child nodes. This functionality led to the discovery of the common links amongst the factors, as shown in Fig. 3, 4 and 5 .

The observation of participants provided more insight into feelings and attitudes towards e-services. This combined with the iterative comparative nature of grounded theory showed factors that were related to each other. These links and relations were also clear in the memos and mind maps. The feedback from participants can be used to further break down the categories above as follows (see Fig. 2):

1. Customer attitude relates to the personal aspect, that is, the users' preference and feelings towards the online system.

2. System functionality refers to the technical aspects of the online system, for example, the system performance.

3. Need for purpose and use is associated with determining if there is value added from using the online system.

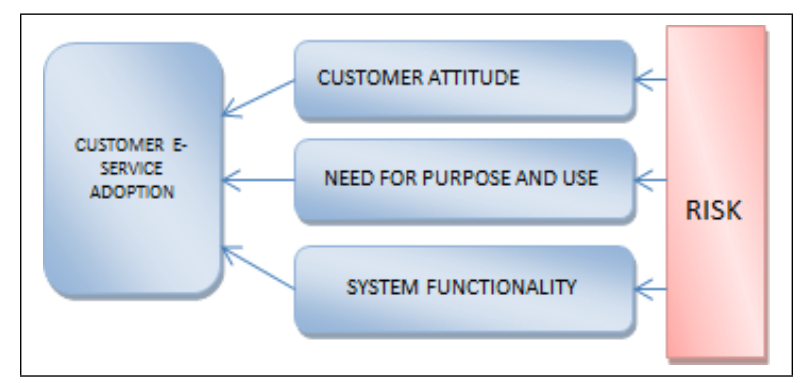

Figure 2: First-order overview of the factors that influence customer e-services adoption

The research results showed that the risk factor was prevalent over all categories. All participants mentioned the risk factor. They feared identity theft and financial loss due to fraud. This impacts the customer's perception of an e-service which directly impacts customer e-service adoption/rejection.

Fig. 3 illustrates the common factors and relationships for the sub-category 'need for purpose'. Relevant content has an impact on: satisfying of customer requirements, techno-stress, customer trust, loyalty and social influence; customer support; customisation, and the time factor. Accurate and up-to-date content reduces frustration which, in turn, reduces techno-stress. Relevant content leads to satisfied customers which, in turn, lead to customers returning to the e-service. Relevant content also reduces the time taken to complete a purchase as the customer will spend little time on searching for the required information. Customisation has an impact on: customer trust, loyalty and social influence; the time factor, relevant content, satisfying of customer requirements, and user friendly-system and familiarity. Customisation is where customers' suggestions are taken into consideration regarding the eservice content. This reduces the time required to complete a purchase because the customer's requirements are met. A common link was identified where customisation and relevant content both impact: customer 


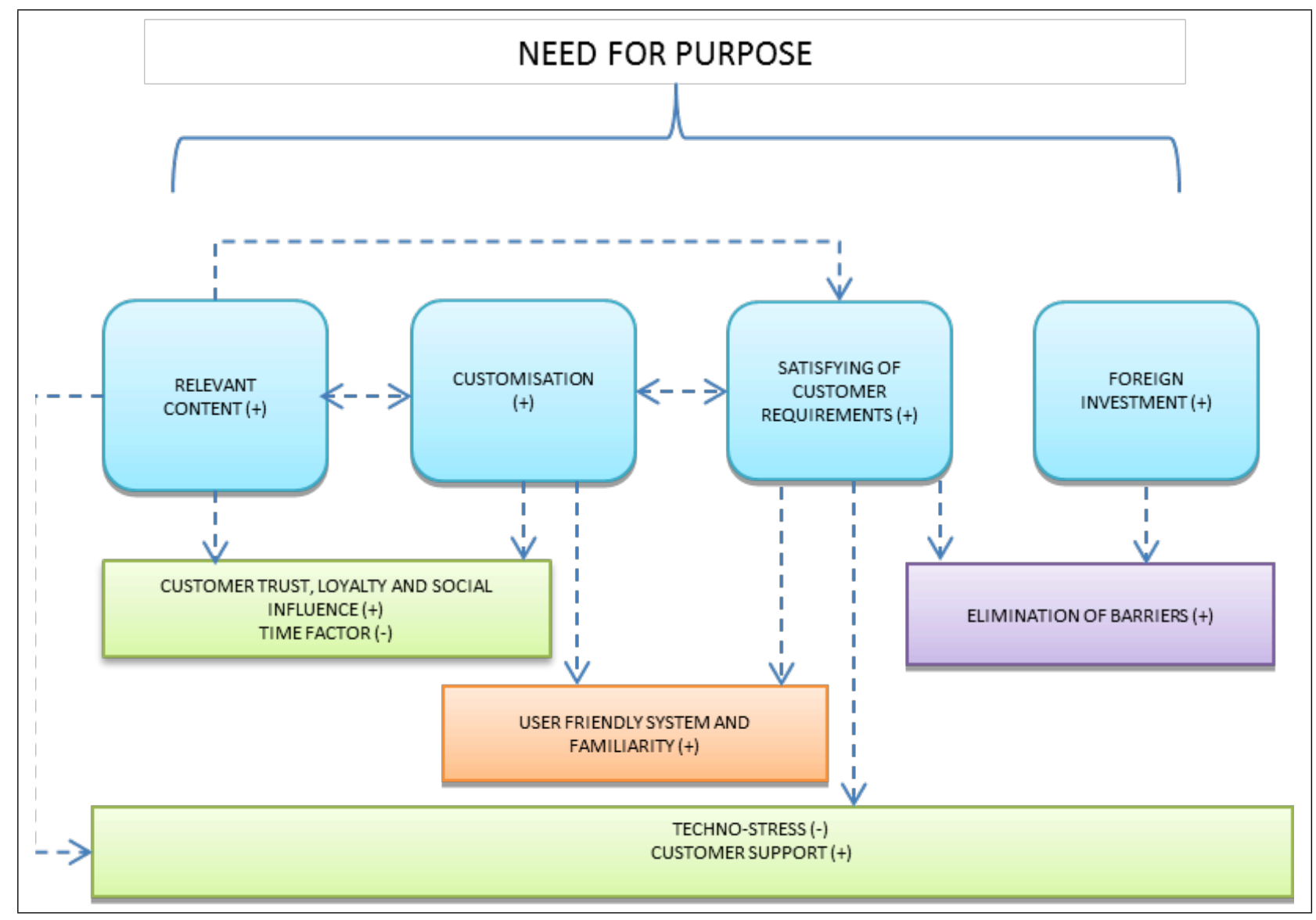

Figure 3: Second-order overview of the relationships for the sub-category 'need for purpose'

trust, loyalty and social influence, and the time factor. Customisation refers to satisfying the customer's needs in terms of the content and functionality of the e-service. Customers return to an e-service that contains relevant information because this reduces the shopping time. Satisfying of customer requirements has an impact on: user friendliness of the system and familiarity, techno-stress, elimination of barriers, customisation and customer support. Systems that are easy to navigate and that have online support available lead to e-service adoption. Online support increased customer satisfaction as problems could be resolved immediately, for example, in the case of call centres. Inflow of foreign exchange impacts on elimination of barriers - that is, an increase in international shoppers will lead to an increase in inflow of foreign exchange.

Fig. 4 illustrates the common factors and relationships for the sub-category 'system functionality'. A common link was identified where the time factor impacts: customisation, relevant content, and satisfying of customer requirements. Customisation refers to making changes depending on the customer's suggestions. This leads to familiarity of use which saves time in completing a purchase. The research results showed that relevant content allowed participants to make decisions easily and that this saved time when completing a purchase. Many participants indicated that saving time led to customer satisfaction. Another common link was where recovery from system failure and the time factor impact, i.e. user-friendly system and familiarity and customer support. The research showed that participants could easily navigate userfriendly systems which saved time. Available online assistance made it possible to efficiently and speedily resolve system failures, for example, where icons where not responsive. Delivery performance has an impact on: customer trust, loyalty and social influence; technostress, time to recover from system failure, and the time factor. Techno-stress is where participants experience difficulties due to very little IT knowledge or experience, or due to complicated systems. These difficulties created a negative perception of the e-service and led to delays in concluding online purchases. Poor delivery performance was seen to create negative customer perception of e-services. For example, an e-service that has technical failures encouraged participants to rather shop in a physical store.

Fig. 5 illustrates the common factors and relationships for the sub-category 'customer attitude'. Elimination of barriers impacts: the time factor and satisfying of customer requirements. This refers to how easily and quickly an online purchase may be concluded. Customer trust, loyalty and social influence impact: spontaneous delight, satisfying of customer requirements, relevant content, customisation, delivery performance, preference for a popular e-service, customer support, and techno-stress. These factors influence the participant's perception of the e-service. A positive perception will increase e-service adoption. Techno-stress impacts: customer trust, loyalty and social influence; 


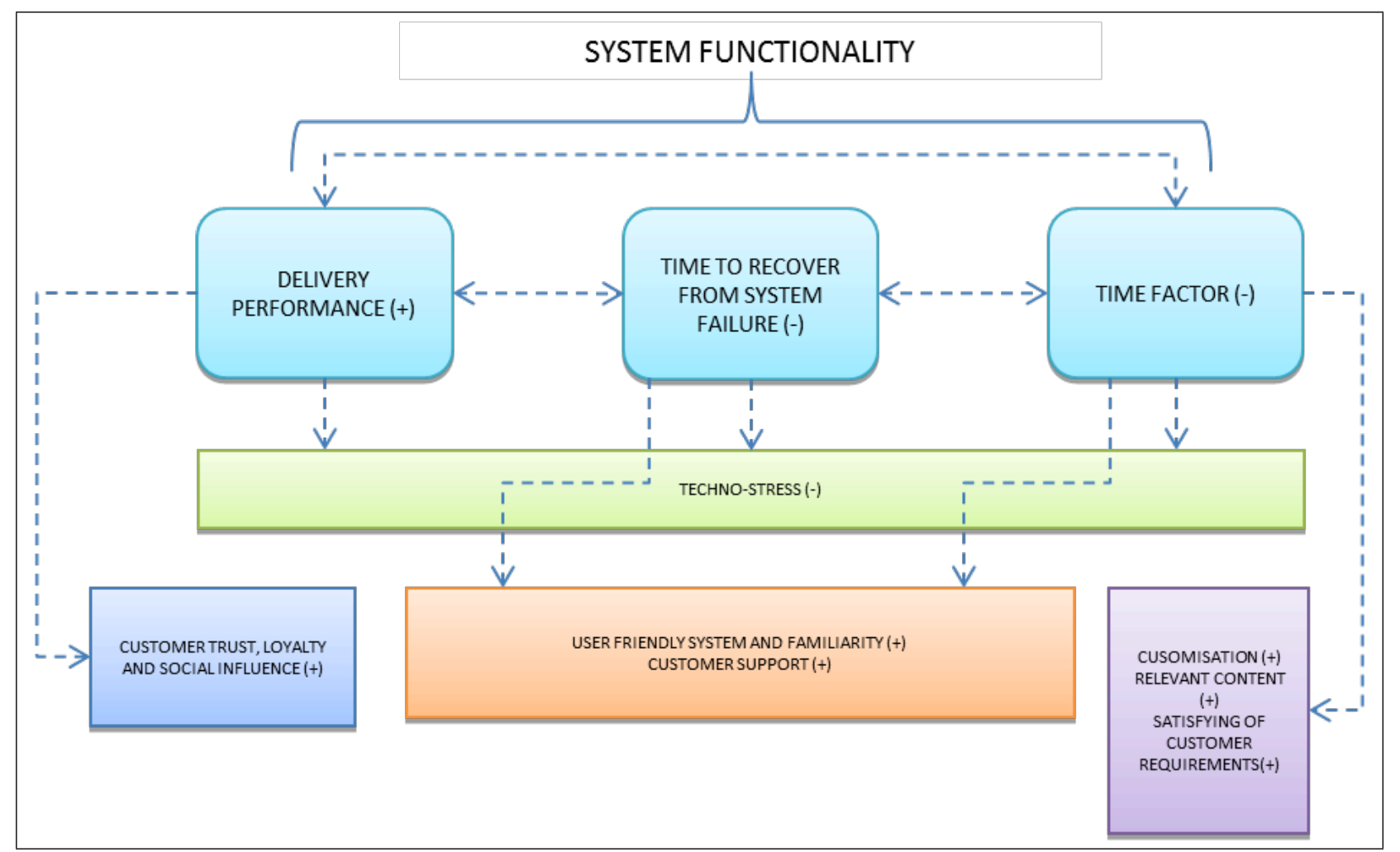

Figure 4: Second-order overview of the relationships for the sub-categories of system functionality

delivery performance, time to recover from system failure, relevant content, customisation, the time factor, satisfying of customer requirements, customer support, and user-friendly system and familiarity. A decrease in techno-stress leads to e-service adoption. User-friendly system and familiarity impacts: techno-stress, the time factor, satisfying of customer requirements, time to recover from system failure, customisation, customer support, and customer trust, loyalty and social influence. Customer support impacts: user-friendly system and familiarity, techno-stress, customer trust, loyalty and social influence; satisfying of customer needs, time to recover from system failure, relevant content, and the time factor. Online customer support took the form of email, telephone, online documentation, online videos, and chat. The research indicated that participants favoured e-services where online support was easily accessible and where the response time for queries was within 24 hours. Resolving customer issues online eases the frustration of system faults. Relevant content resulted in customers returning to a particular e-service. Research showed that where customers' suggestions were incorporated into the e-service, those customers returned to the e-service, there were fewer technical issues, and there was ease in completing a purchase. It was discovered that customers will return to an e-service where they have experienced no technical challenges. Customer trust, loyalty and social influence impact both spontaneous delight and preference for a popular e-service. Research showed that spontaneous delight, in the form of discounts, increased customer satisfaction as compared to no surprise offers. E-services that are utilised more than others gain the customer's trust. Interrelated relationships between individual factors were also discovered. As presented in the diagram, the following factors impact each other: customer trust, loyalty, and social influence; techno-stress, user-friendly system and familiarity, and customer support. That is, any change in any factor in the grouping above will impact all the factors in the group.

\section{SIGNIFICANCE OF THE CONCEPTUAL FRAMEWORK}

This framework aims to bridge the gap between organisations and customers, by highlighting key considerations for meeting customer need, using e-services. The proposed framework attempts to resolve flaws and gaps that exist in previous studies.

Businesses are now operating differently by placing more emphasis on customer satisfaction, in doing so, creating competitive advantage [31. This will also lead to improved service delivery within South Africa.

Understanding customer needs leads to loyal customers. It is less costly to maintain loyal customers than to attract new customers. This study aims to reduce the cost of running a business by understanding the customer 31. This framework will help to identify customer trends and preferences.

Promoting the automation of manual service delivery processes creates innovation and new challenges within the information society. Innovative ideas can lead to job creation in South Africa. Job creation will result in a better quality of life.

Fewer barriers will exist within the e-Business 


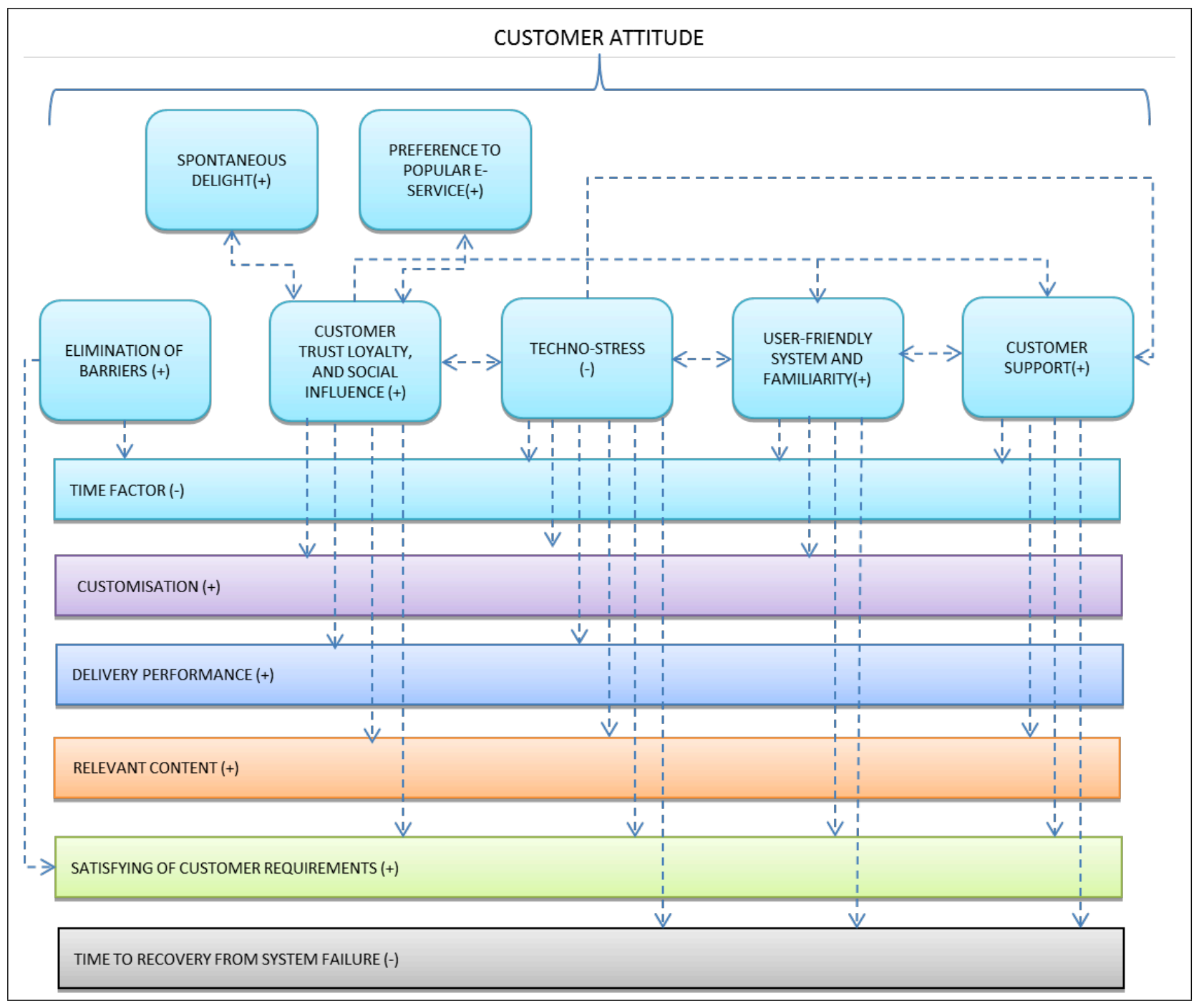

Figure 5: Second-order overview of the relationships for the sub-categories of customer attitude

world. Technology opens a world of opportunities for online business [10]. This creates more product and service variety for customers.

E-services also reduce the administrative tasks and paper work that is associated with providing a service or product.

\section{DEMONSTRATION OF VALIDITY AND RE- LIABILITY}

Charmaz 52 proposed the indicators of credibility, resonance, originality and usefulness as techniques to establish 'validity' in constructivist grounded theory. She listed several questions that should be answered in order to establish validity. In table 5 the criteria proposed by Charmaz [52] are used to test the validity of the study undertaken. Charmaz 52 indicates that 'a strong combination of originality and credibility increasing resonance, usefulness and the subsequent value of the contribution' can be used to ensure validity. The study presented in this paper is original within the context of online shopping in South Africa and credibility is achieved by using more than one data collection method to triangulate the results. As done in this study - data was collected by using surveys, interviews and observations. Additionally the second author of this article independently reviewed the coding and provided feedback to the first author with regard to the interpretation of the results. The NVivo tool was chosen to organise the data collected. This structure in research and orderly arrangement of data reduces biasness and enhances the data analysis phase [52]. 
Table 5: Showing the criteria used to ensure validity based on the framework proposed by Charmaz [52]

\begin{tabular}{|c|c|c|}
\hline Criteria & Sub-criteria (cited from Charmaz [52]) & Evidence of compliance \\
\hline \multirow{5}{*}{ Resonance } & $\begin{array}{l}\text { 'Do the categories portray the fullness of the } \\
\text { studied experience?' }\end{array}$ & $\begin{array}{l}\text { Categories were identified from the literature } \\
\text { and new factors also were allowed to emerge. }\end{array}$ \\
\hline & $\begin{array}{l}\text { 'Have you revealed both liminal and unstable } \\
\text { taken-for-granted meanings?' }\end{array}$ & $\begin{array}{l}\text { 'Have you revealed both liminal and unstable } \\
\text { taken-for-granted meanings?' }\end{array}$ \\
\hline & $\begin{array}{l}\text { 'Have you drawn links between larger collectiv- } \\
\text { ities or institutions and individual lives, when } \\
\text { the data so indicates?' }\end{array}$ & The conceptual model is in evidence. \\
\hline & $\begin{array}{l}\text { 'Does your grounded theory make sense to } \\
\text { your participants or people who share their } \\
\text { circumstances?' }\end{array}$ & The second author reviewed the methodology \\
\hline & $\begin{array}{l}\text { 'Does your analysis offer them deeper insights } \\
\text { about their lives and worlds?' }\end{array}$ & $\begin{array}{l}\text { Face-to-face interviews and observations led } \\
\text { to deeper insight about the phenomenon. }\end{array}$ \\
\hline \multirow{6}{*}{ Credibility } & $\begin{array}{l}\text { 'Has your research achieved intimate familiar- } \\
\text { ity with the setting or topic?' }\end{array}$ & " A prolonged study allowed for familiarity. \\
\hline & $\begin{array}{l}\text { 'Is the data sufficient to merit your claims? } \\
\text { Consider the range, number, and depth of } \\
\text { observations contained in the data.' }\end{array}$ & $\begin{array}{l}\text { There is sufficient data- } 3 \text { modes of data col- } \\
\text { lection and large sample }(n=70)\end{array}$ \\
\hline & $\begin{array}{l}\text { 'Have you made systematic comparisons be- } \\
\text { tween observations and between categories?' }\end{array}$ & $\begin{array}{l}\text { Multi-methods which included observations } \\
\text { led to systematic comparisons during analysis }\end{array}$ \\
\hline & $\begin{array}{l}\text { 'Do the categories cover a wide range of em- } \\
\text { pirical observations?' }\end{array}$ & $\begin{array}{l}\text { The sample size }(n=70) \text { ensured a wide range } \\
\text { of observations. }\end{array}$ \\
\hline & $\begin{array}{l}\text { 'Are there strong logical links between the } \\
\text { gathered data and your argument and analy- } \\
\text { sis?' }\end{array}$ & $\begin{array}{l}\text { NVivo tool allowed for an independent logical } \\
\text { link and matched theory to data. }\end{array}$ \\
\hline & $\begin{array}{l}\text { 'Has your research provided enough evidence } \\
\text { for your claims to allow the reader to form an } \\
\text { independent assessment-and agree with your } \\
\text { claims?' }\end{array}$ & $\begin{array}{l}\text { The researcher conducted an in-depth liter- } \\
\text { ature review and included multi-methods of } \\
\text { data collection which included observation. }\end{array}$ \\
\hline \multirow{4}{*}{ Usefulness } & $\begin{array}{l}\text { 'Does your analysis offer interpretations that } \\
\text { people can use in their everyday worlds?' }\end{array}$ & $\begin{array}{l}\text { It is evident that the conceptual model which } \\
\text { shows the linkages between the categories will } \\
\text { be useful to e-commerce development. }\end{array}$ \\
\hline & $\begin{array}{l}\text { 'Do your analytic categories suggest any } \\
\text { generic processes? If so, have you examined } \\
\text { these generic processes for tacit implications?' }\end{array}$ & $\begin{array}{l}\text { The conceptual model was viewed from a first- } \\
\text { order view and a second-order viewpoint. }\end{array}$ \\
\hline & $\begin{array}{l}\text { 'Can the analysis spark further research in } \\
\text { other substantive areas?' }\end{array}$ & $\begin{array}{l}\text { The analysis did spark future research direc- } \\
\text { tions. }\end{array}$ \\
\hline & $\begin{array}{l}\text { 'How does your work contribute to knowledge? } \\
\text { How does it contribute to making a better } \\
\text { world?' }\end{array}$ & $\begin{array}{l}\text { It contributes by providing a guideline for e- } \\
\text { services to foster customer e-services adoption } \\
\text { which leads to economic empowerment. }\end{array}$ \\
\hline \multirow{4}{*}{ Originality } & $\begin{array}{l}\text { 'Are your categories fresh? Do they offer new } \\
\text { insights? Does your analysis provide a new } \\
\text { conceptual rendering of the data?' }\end{array}$ & $\begin{array}{l}\text { There are few studies within the South African } \\
\text { context that establish the relative significance } \\
\text { of the factors that influence e-services. }\end{array}$ \\
\hline & $\begin{array}{l}\text { 'Does your analysis provide a new conceptual } \\
\text { rendering of the data?' }\end{array}$ & $\begin{array}{l}\text { The conceptual model provides a multi- } \\
\text { dimensional view of the factors that influence } \\
\text { e-services adoption }\end{array}$ \\
\hline & $\begin{array}{l}\text { 'What is the social and theoretical significance } \\
\text { of this work?' }\end{array}$ & $\begin{array}{l}\text { It contributes to the existing body of knowl- } \\
\text { edge and to sustainability of e-services in } \\
\text { South Africa. }\end{array}$ \\
\hline & $\begin{array}{l}\text { 'How does your grounded theory challenge, } \\
\text { extend, or refine current ideas, concepts, and } \\
\text { practices?' }\end{array}$ & $\begin{array}{l}\text { The study does refine existing ideas regarding } \\
\text { e-services in the South African context. }\end{array}$ \\
\hline
\end{tabular}


Table 6: Criteria to evaluate validity and reliability based on the framework by Sikolia et al. 63.

\begin{tabular}{|c|c|c|}
\hline Criteria & Techniques proposed by Sikolia et al. 63 & Evidence of compliance \\
\hline Credibility & $\begin{array}{l}\text { - Prolonged engagement with participants } \\
\text { - Triangulation of data } \\
\text { - Thick descriptions } \\
\text { - Participant guidance of the inquiry } \\
\text { - Use of participant words in the emerging } \\
\text { theory } \\
\text { - Peer debriefs } \\
\text { - Negative Case Analysis }\end{array}$ & $\begin{array}{l}\text { - Study carried over a prolonged period of } \\
\text { time (1 year) } \\
\text { - Triangulation via multi-methods } \\
\text { - Thick descriptions provided in the analy- } \\
\text { sis } \\
\text { - Participants guided the results of the } \\
\text { study } \\
\text { - Quotations from participants were in- } \\
\text { cluded in the analysis } \\
\text { - The second author conducted the peer } \\
\text { analysis } \\
\text { - Categories that did not fit in with the } \\
\text { expectations of the researcher were con- } \\
\text { sidered. }\end{array}$ \\
\hline Transferability & $\begin{array}{l}\text { - Thick descriptions of the research meth- } \\
\text { ods }\end{array}$ & $\begin{array}{l}\text { External validity was assured by using random } \\
\text { participants at random times and by using a } \\
\text { large sample size }(n=70) \text {. Also the analysis } \\
\text { provided 'thick descriptions' of the research, } \\
\text { participants, methodology and the concep- } \\
\text { tual model. Transferability was ensured by } \\
\text { the constant comparative nature of Grounded } \\
\text { Theory methodology. Transferability was en- } \\
\text { sured by providing clear descriptions of the } \\
\text { methodology to ensure repeatability. }\end{array}$ \\
\hline Dependability & $\begin{array}{l}\text { - Examination of a detailed audit by an } \\
\text { observer }\end{array}$ & $\begin{array}{l}\text { The second author played the role of an ob- } \\
\text { server and ensured that the methodology was } \\
\text { adhered to. }\end{array}$ \\
\hline Confirmability & $\begin{array}{l}\text { - Examination of a detailed audit by an } \\
\text { observer }\end{array}$ & $\begin{array}{l}\text { The second author who was not involved in the } \\
\text { data collection or the analysis confirming the } \\
\text { results. Confirmability was also ensured by } \\
\text { mapping the existing literature that described } \\
\text { similar results to the research of customer } \\
\text { e-service adoption [2, 3, 64, 65. }\end{array}$ \\
\hline
\end{tabular}


Given the flexibility of grounded theory methodology, the researcher was able to also demonstrate validity and reliability from a positivistic viewpoint. In the next evidence of validity and reliability, the criteria from Licoln and Guba 54 are used as a framework for compliance. The criterions include: credibility, transferability, dependability and confirmability. The criterions for trustworthiness from Lincoln and Guba 54 and the procedures recommend by Sikolalia et al. 63 for demonstrating validity and reliability in grounded theory studies were considered as they are germane to this study.

The steps involved in grounded theory method were used to ensure trustworthiness. This allows the researcher to explore, discover and interpret data. The methodology allowed for 'thick descriptions' to emerge which is of one the steps recommended to ensure trustworthiness in grounded theory studies by Sikolia et al. 63] and together with triangulation contributes towards establishing 'trustworthiness credibility'. External validity seeks to find the domain to which the findings can be generalised and can be ensured by using random participants at random times. This will create unique situations in which to repeat the same test cases 66. Tests were repeated at varying times with random participants. The results from these tests will be compared and analysed thus establishing 'trustworthiness transferability'. Bashir et al. 66 asserts that while reliability is a divisive topic in qualitative research, it also can be assured by examining the trustworthiness of a study. Sikolia et al. 63. suggests that the auditing of the grounded theory steps by an observer would satisfy reliability (i.e. 'trustworthiness dependability'). In this research the steps and the emergent data was reviewed and refined by the second author who also established the objectivity of the study.

As summarised in Table 6, most of the criteria were satisfied; however, the validity measure of 'respondent validation' was not considered formally in the study, as the next phase of the research involved a quantitative study to validate the results of the grounded theory study.

\section{CONCLUSION}

Web based transacting is growing rapidly daily in the form of self-services and e-commerce. It is imperative to understand the factors that encourage/discourage shoppers to use an e-service as compared to face-toface shopping. Organisations that have a view of the customer's perception are better equipped to benefit from e-services. The customer's perception is the key to the adoption/rejection of the use of e-services. This study aimed to uncover the factors that impact the customer's perception. This will lead to understanding the significance of these factors on customer e-service adoption. The main objective of this study was to develop a conceptual framework to show the correlation relationships among the factors that impact e-service adoption/rejection and the relative significance of the factors that influence the customer's e-service adoption.
Grounded theory methodology was used to achieve the objective. The advantage of the use of grounded theory for this study was the clearly defined steps in the process. Also, all data must be grounded which makes the research more rigorous, reliable, valid and flexible. Grounded theory was suitable in building the conceptual framework as it provided the researcher with a foundation to build on and enhance the study of e-service adoption. The step by step process gave the researcher an ordered approach to analysis. This structure led to accuracy and validity. The limitation of grounded theory was that it is very time consuming.

The three main categories that identified were: customer attitude, system functionality and need for purpose. It was discovered that the risk factor was prevalent throughout the research, that is, risk impacted all factors that led to adoption/rejection of e-services. The three main categories were further broken down according to the findings. Need for purpose focussed on the effects of relevant content, customisation, satisfying of customer requirements and foreign investment. System functionality focussed on the effects of system performance, time to recover from system failure and the overall time factor. Customer attitude focussed on the effects of spontaneous delight, preference to popular e-service, elimination of barriers, customer trust, loyalty and social influence, techno-stress, user-friendly systems and familiarity, and customer support. All the factors mentioned above impact the adoption/rejection of e-services.

Customer satisfaction is a key concern in any business strategy. The customer's perception impacts customer satisfaction, that is, a positive perception of e-service use increases e-service adoption. Managers within organisations can use this study to understand customers better. This will improve customer services within South Africa. The factors and interrelationships identified in this study can be included in business strategies as focal points to improve customer satisfaction and increase profit margins. It is intended that future research will involve a quantitative survey to test the validity of the framework presented in this paper.

This study delivered a conceptual model. This conceptual model is the key to understanding customers which will lead to building stronger e-service strategies. A solid strategy will retain customers and improve customer services within South Africa. The conceptual model lists the factors that organisations should place focus on. Especially those that are of high significance, for example, satisfying customer needs, avoidance of techno-stress, relevant content and spontaneous delight. The conceptual model also served as a useful research model. The ordered and structured nature of the model allowed for in depth and systematic analysis. The conceptual framework provided a clear view of the focus areas. This kept the study on the path of relevance. 


\section{FUTURE WORK}

Future work entails quantitative research to validate the conceptual framework. The research will also uncover the level of significance that each factor has on customer satisfaction. One of the limitations of the study is that data was collected from one organisation only. A more diverse sample, including more than one organisation will contribute to the research. That is, various age groups, cultural beliefs and experience in using online shopping. Future studies would involve conducting research in an alternative setting to verify the validity of the results. Shopping online is rapidly growing due to the Internet and mobile technology and social media. There are three aspects that require further investigation and that will add value to the consumers' shopping experiences. These aspects are:

- Online shopping policies-Many consumers bypass reading the terms and conditions and other shopping policies online. Most of these policies contain information to protect the consumer and service provider. It will be beneficial for consumers to understand the policies that protect online shoppers.

- Online shopping mobile applications - The use of mobile technology is increasing. This study did not focus on the online shopping mobile applications that are available and the consumers' attitude towards these applications.

- Cloud technology - This relates to the sharing of resources that enable an e-service to function at high performance.

\section{REFERENCES}

[1] J. Rowley. "An analysis of the e-service literature: Towards a research agenda". Internet research, vol. 16, no. 3, pp. 339-359, 2006. DOI http://dx.doi.org/ $10.1108 / 10662240610673736$

[2] K. Lee and K. Joshi. "An empirical investigation of customer satisfaction with technology mediated service encounters in the context of online shopping". Journal of information technology management, vol. 18, no. 2, pp. 18-37, 2007.

[3] M. Tarafdar, Q. Tu and T. Ragu-Nathan. "Impact of technostress on end-user satisfaction and performance". Journal of management information systems, vol. 27, no. 3, pp. 303-334, 2010. DOI http: //dx.doi.org/10.2753/MIS0742-1222270311

[4] M. S. Featherman and P. A. Pavlou. "Predicting e-services adoption: A perceived risk facets perspective". International journal of human-computer studies, vol. 59, no. 4, pp. 451-474, 2003. DOI http: //dx.doi.org/10.1016/S1071-5819(03)00111-3

[5] M. S. Featherman and J. D. Wells. "The intangibility of e-services: Effects on perceived risk and acceptance". ACM SIGMIS database, vol. 41, no. 2, pp. 110-131, 2010. DOI http://dx.doi.org/10.1145/ 1795377.1795384

[6] R. T. Rust and P. Kannan. "The era of e-service". In E-service: New directions in theory and practice, pp. 3-24. Armonk, NY: ME Sharpe, 2002.
[7] M. J. Bitner, S. W. Brown and M. L. Meuter. "Technology infusion in service encounters". Journal of the academy of marketing Science, vol. 28, no. 1, pp. 138-149, 2000. DOI http://dx.doi.org/10.1177/ 0092070300281013

[8] H. Singh. "The importance of customer satisfaction in relation to customer loyalty and retention". Journal of the academy of marketing science, vol. 60, pp. 193-225, 2006.

[9] K. Eriksson and D. Nilsson. "Determinants of the continued use of self-service technology: The case of Internet banking". Technovation, vol. 27, no. 4, pp. 159-167, 2007. DOI http://dx.doi.org/10.1016/j technovation.2006.11.001.

[10] R. Cenfetelli, I. Benbasat and S. Al-Natour. "Information technology mediated customer service: A functional perspective". In D. E. Avison and D. F. Galletta (editors), Proceedings of the international conference on information systems (ICIS 2005). Las Vegas, NV, USA, December 2005. 2005.

[11] J. Kandampully. "Innovation as the core competency of a service organisation: The role of technology, knowledge and networks". European journal of innovation management, vol. 5, no. 1, pp. 18-26, 2002. DOI http: //dx.doi.org/10.1108/14601060210415144

[12] A. Abubakar and R. B. H. Tasmin. "The impact of information and communication technology on banks' performance and customer service delivery in the banking industry". International journal of latest trends in finance and economic sciences, vol. 2, no. 1, 2012.

[13] R. G. Javalgi, C. L. Martin and P. R. Todd. "The export of e-services in the age of technology transformation: Challenges and implications for international service providers". Journal of services marketing, vol. 18, no. 7, pp. 560-573, 2004. DOI http: //dx.doi.org/10.1108/08876040410561884

[14] D.-D. Nguyen and D. Kira. "Trust and quality assurance in business-to-consumer electronic commerce: Enhancing consumer acceptance and participation". In PACIS 2000 Proceedings, p. 38. 2000.

[15] M. I. Eid. "Determinants of e-commerce customer satisfaction, trust, and loyalty in Saudi Arabia". Journal of electronic commerce research, vol. 12, no. 1, pp. 78-93, 2011.

[16] N. Kassim and N. Asiah Abdullah. "The effect of perceived service quality dimensions on customer satisfaction, trust, and loyalty in e-commerce settings: A cross cultural analysis". Asia-Pacific journal of marketing and logistics, vol. 22, no. 3, pp. 351-371, 2010. DOI http://dx.doi.org/10.1108/ 13555851011062269

[17] M. K. Lee, N. Shi, C. M. Cheung, K. H. Lim and C. L. Sia. "Consumer's decision to shop online: The moderating role of positive informational social influence". Information $\&$ management, vol. 48, no. 6, pp. 185-191, 2011. DOI http://dx.doi.org/10.1016/j. im.2010.08.005.

[18] R. T. Rust and K. N. Lemon. "E-service and the consumer". International journal of electronic commerce, vol. 5, no. 3, pp. 85-101, 2001.

[19] T. Ragu-Nathan, M. Tarafdar, B. S. Ragu-Nathan and Q. Tu. "The consequences of technostress for end users in organizations: Conceptual development and 
empirical validation". Information systems research, vol. 19, no. 4, pp. 417-433, 2008. DOI http://dx doi.org/10.1287/isre.1070.0165.

[20] Q. Tu, M. Tarafdar, T. Ragu-Nathan and B. S. RaguNathan. "Improving end-user satisfaction through techno-stress prevention: Some empirical evidences". In AMCIS 2008 proceedings, p. 236. 2008.

[21] C. Demangeot and A. J. Broderick. "Conceptualising consumer behaviour in online shopping environments". International journal of retail $\&$ distribution management, vol. 35, no. 11, pp. 878-894, 2007. DOI http: //dx.doi.org/10.1108/09590550710828218

[22] E. Cristobal, C. Flavián and M. Guinaliu. "Perceived e-service quality (PeSQ) measurement validation and effects on consumer satisfaction and web site loyalty". Managing service quality: An international journal, vol. 17 , no. 3, pp. 317-340, 2007.

[23] J. N. Morfaw. Total quality management (TQM): A model for the sustainability of projects and programs in Africa. University Press of America, 2009.

[24] J. A. Ward. "Meeting customer requirements first time, every time". Information systems management, vol. 11, no. 3, pp. 75-78, 1994. DOI http://dx.doi org/10.1080/07399019408964657

[25] D. C. Chou. "Integrating TQM into e-commerce". Information systems management, vol. 18 , no. 4, pp. 3139, 2001. DOI http://dx.doi.org/10.1201/1078/ 43198.18.4.20010901/31463.4

[26] B. L. Bayus. "Kano model of customer satisfaction". In Wiley international encyclopedia of marketing. Wiley Online Library, 2010.

[27] A. Fundin and L. Nilsson. "Using Kano's theory of attractive quality to better understand customer experiences with e-services". Asian journal on quality, vol. 4, no. 2, pp. 32-49, 2003. DOI http://dx.doi. org/10.1108/15982688200300018

[28] W. Wang, T. Lu, C. Huang and A. Liu. "The application of Kano model in the study of e-service quality". Journal of information technology and application, vol. 1, no. 1, pp. 37-45, June 2006.

[29] P. Zhang and G. M. von Dran. "User expectations and rankings of quality factors in different web site domains". International journal of electronic commerce, vol. 6 , no. 2, pp. 9-33, 2001.

[30] N. Kano, N. Seraku, F. Takahashi and S. Tsuji. "Attractive quality and must-be quality". Journal of the Japanese society for quality control, 1984.

[31] K. Matzler and H. H. Hinterhuber. "How to make product development projects more successful by integrating Kano's model of customer satisfaction into quality function deployment". Technovation, vol. 18, no. 1 , pp. $25-38,1998$. DOI http://dx.doi.org/10 1016/S0166-4972(97)00072-2

[32] M. Al Kailani and R. Kumar. "Investigating uncertainty avoidance and perceived risk for impacting Internet buying: A study in three national cultures". International journal of business and management, vol. 6, no. 5, p. p76, 2011. DOI http: //dx.doi.org/10.5539/ijbm.v6n5p76.

[33] South African consumer satisfaction index. "South African consumer satisfaction index", 2013. URL http: //www.sacsi.biz
[34] M. Kyobe. "Investigating the key factors influencing ICT adoption in South Africa". Journal of systems and information technology, vol. 13, no. 3, pp. 255-267, 2011. DOI http://dx.doi.org/10.1108/ 13287261111164844

[35] S. M. Mutula and J. Mostert. "Challenges and opportunities of e-government in South Africa". The electronic library, vol. 28 , no. 1 , pp. 38 53, 2010. DOI http://dx.doi.org/10.1108/ 02640471011023360

[36] R. Matavire and I. Brown. "Investigating the use of grounded theory in information systems research". In Proceedings of the 2008 annual research conference of the South African Institute of Computer Scientists and Information Technologists on IT research in developing countries, pp. 139-147. ACM, 2008. DOI http://dx. doi.org/10.1145/1456659.1456676

[37] J. Hughes and S. Jones. "Reflections on the use of grounded theory in interpretive information systems research". In Proceedings of the 11th European conference on information systems, Naples, Italy June 2003, pp. 833-845. 2003.

[38] T. M. Egan. "Grounded theory research and theory building". Advances in developing human resources, vol. 4, no. 3, pp. 277-295, 2002. DOI http://dx.doi org/10.1177/1523422302043004

[39] B. G. Glaser. Theoretical sensitivity: Advances in the methodology of grounded theory, vol. 1. Sociology Press, 1978.

[40] A. L. Strauss, J. M. Corbin et al. Basics of qualitative research, vol. 15. Sage Newbury Park, CA, 1990.

[41] R. Hoda, J. Noble and S. Marshall. "Grounded theory for geeks". In Proceedings of the 18th conference on pattern languages of programs, p. 24. ACM, 2011. DOI http://dx.doi.org/10.1145/2578903. 2579162

[42] J. A. Holton. "Grounded theory as a general research methodology". The grounded theory review, vol. 7, no. 2, pp. 67-93, 2008.

[43] B. Glaser and A. Strauss. The discovery of grounded theory: Strategies for qualitative research. Chicago: Aldine, 1967.

[44] B. G. Glaser. Examples of grounded theory: A reader. Sociology Press, 1993.

[45] K. Charmaz. "Grounded theory methodology: Objectivist and constructivist qualitative methods". In Handbook of qualitative research, pp. 509-535. Sage, 2nd edn., 2000.

[46] B. Glaser. "Constructivist grounded theory". Quantitative social research, vol. 3, no. 3, pp. 1-20, September 2002.

[47] D. Walker and F. Myrick. "Grounded theory: An exploration of process and procedure". Qualitative health research, vol. 16 , no. 4, pp. 547-559, 2006. DOI http: //dx.doi.org/10.1177/1049732305285972

[48] U. M. Devadas, A. D. Silong and I. A. Ismail. "The relevance of Glaserian and Straussian grounded theory approaches in researching human resource development". In International conference on financial management and economics (Hong Kong, China July 2011). 2011. 
[49] K. Williamson. "The broad methodological contexts of information literacy research". Exploring methods in information literacy research, pp. 1-12, 2007.

[50] S. B. Merriam. Qualitative research: A guide to design and implementation. John Wiley \& Sons, 2014.

[51] J. Creswell. Research design: Qualitative, quantitative, and mixed methods approaches. SAGE Publications, Incorporated, 2009.

[52] K. Charmaz. Constructing grounded theory: A practical guide through qualitative research. Sage Publications Ltd, London, 2006.

[53] J. W. Creswell and D. L. Miller. "Determining validity in qualitative inquiry". Theory into practice, vol. 39 no. 3, pp. 124-130, 2000. DOI http://dx.doi.org/ 10.1207/s15430421tip3903_2

[54] Y. S. Lincoln and E. G. Guba. Naturalistic inquiry, vol. 75. Sage, 1985.

[55] R. F. Chiovitti and N. Piran. "Rigour and grounded theory research". Journal of advanced nursing, vol. 44, no. 4, pp. 427-435, 2003. DOI http://dx.doi.org/ $10.1046 / \mathrm{j} .0309-2402.2003 .02822 . \mathrm{x}$

[56] N. Lee, J. Saunders and C. Goulding. "Grounded theory, ethnography and phenomenology: A comparative analysis of three qualitative strategies for marketing research". European journal of marketing, vol. 39, no. 3/4, pp. 294-308, 2005. DOI http: //dx.doi.org/10.1108/03090560510581782

[57] C. Urquhart. "An encounter with grounded theory: Tackling the practical and philosophical issues". Qualitative research in IS: Issues and trends, pp. 104-140, 2000 .

[58] J. D. Bringer, L. H. Johnston and C. H. Brackenridge. "Using computer-assisted qualitative data analysis software to develop a grounded theory project". Field methods, vol. 18, no. 3, pp. 245-266, 2006. DOI http: //dx.doi.org/10.1177/1525822X06287602.

[59] B. G. Glaser and J. Holton. "Remodeling grounded theory". In Forum qualitative Sozialforschung/Forum: Qualitative social research. 2004.

[60] N. Mavetera and J. H. Kroeze. "Practical considerations in grounded theory research". Tech. rep., Sprouts: Working papers on information systems, 2009.

[61] D. Flint, B. Gammelgaard, W. S. Randall and J. E. Mello. "Grounded theory: An inductive method for supply chain research". International journal of physical distribution $\mathcal{E}$ logistics management, vol. 42, no. 8/9, pp. 863-880, 2012. DOI http://dx.doi.org/10. $1108 / 09600031211269758$

[62] H. E. T. Dixon. A grounded theory of the dynamic nature of constraints to leisure and successful coping process. ProQuest, 2008.

[63] D. Sikolia, D. Biros, M. Mason and M. Weiser. "Trustworthiness of grounded theory methodology research in information systems". In Proceedings of the eighth Midwest Association for Information Systems conference (Normal, Illinois, May 2013). 2013.

[64] J. E. Collier and C. C. Bienstock. "Measuring service quality in e-retailing". Journal of service research, vol. 8 , no. 3, pp. 260-275, 2006. DOI http://dx.doi org/10.1177/1094670505278867
[65] C.-H. Park and Y.-G. Kim. "Identifying key factors affecting consumer purchase behavior in an online shopping context". International journal of retail $\&$ distribution management, vol. 31, no. 1 , pp. 16-29, 2003. DOI http://dx.doi.org/10.1108/ 09590550310457818

[66] M. Bashir, M. T. Afzal and M. Azeem. "Reliability and validity of qualitative and operational research paradigms". Pakistan journal of statistics and operation research, vol. 4, no. 1, pp. 35-45, 2008. DOI http://dx.doi.org/10.18187/pjsor.v4i1.59 


\section{APPENDIX A}

Table 7: Semi-structured interview questions

\begin{tabular}{|l|l|}
\hline Objectives & Questions \\
\hline $\begin{array}{l}\text { To uncover the factors that have a positive impact } \\
\text { on a customer's online shopping experience by using } \\
\text { grounded theory. }\end{array}$ & $\begin{array}{l}\text { What were the most enjoyable factors of your online } \\
\text { shopping experience? }\end{array}$ \\
\hline $\begin{array}{l}\text { To uncover the factors that have a negative impact } \\
\text { on a customers online shopping experience by using } \\
\text { grounded theory. }\end{array}$ & $\begin{array}{l}\text { What were the most frustrating factors of your } \\
\text { online shopping experience? }\end{array}$ \\
\hline $\begin{array}{l}\text { To assess the effect of perceived risk on e-service } \\
\text { adoption in South Africa by identifying the most } \\
\text { prevalent factors that influence customers e-service } \\
\text { adoption. }\end{array}$ & $\begin{array}{l}\text { What are the risks that concern you regarding online } \\
\text { shopping? } \\
\text { Are you comfortable with the level of security offered } \\
\text { on the website? } \\
\text { To what extent does this influence your decision to } \\
\text { shop online or in a physical store? }\end{array}$ \\
\hline $\begin{array}{l}\text { To explore the customers preference for e-services } \\
\text { rather than face-to-face interaction. The customers } \\
\text { perception of an e-service determines the level of cus- } \\
\text { tomer satisfaction, which will determine the adop- } \\
\text { tion or rejection of the e-service. }\end{array}$ & $\begin{array}{l}\text { Would you say that you received a better quality } \\
\text { of service and that it was more convenient to use } \\
\text { the ervice, compared to shopping in a physical } \\
\text { store? Please explain. }\end{array}$ \\
\hline
\end{tabular}




\section{APPENDIX B}

Table 8: Semi-structured interview questions

\begin{tabular}{|c|c|c|}
\hline Category being addressed & No. & Questions \\
\hline Satisfying customer needs & 1 & What is your intention for using the e-service? \\
\hline $\begin{array}{l}\text { User-friendly system, techno-stress, cus- } \\
\text { tomer familiarity }\end{array}$ & 2 & Was it easy to navigate the website? \\
\hline User-friendly system, techno-stress & 3 & $\begin{array}{l}\text { Were you allowed to return to previous actions in } \\
\text { the case of a mistake? }\end{array}$ \\
\hline Risk & 4 & $\begin{array}{l}\text { Does it concern you that this site may misuse your } \\
\text { personal information? }\end{array}$ \\
\hline Risk & 5 & $\begin{array}{l}\text { Does this site use your contact details to send you } \\
\text { spam or unwanted advertisements? }\end{array}$ \\
\hline Relevant content & 6 & $\begin{array}{l}\text { Were the item details you were interested in avail- } \\
\text { able? Price? Delivery options? Payment options? }\end{array}$ \\
\hline Delivery performance & 7 & $\begin{array}{l}\text { Please comment on the waiting time between your } \\
\text { action and the websites response time. }\end{array}$ \\
\hline Recovery from failure & 8 & $\begin{array}{l}\text { Has the website ever crashed in the midst of your } \\
\text { purchase? }\end{array}$ \\
\hline Satisfying customer needs & 9 & $\begin{array}{l}\text { Were your items protected from damage during } \\
\text { delivery? }\end{array}$ \\
\hline Satisfying customer needs & 10 & Were your items delivered on time? \\
\hline Satisfying customer needs & 11 & $\begin{array}{l}\text { Did you receive the correct order in terms of quan- } \\
\text { tity and billing? }\end{array}$ \\
\hline $\begin{array}{l}\text { Customisation, relevant content, satisfy- } \\
\text { ing customer needs, elimination of barriers, } \\
\text { customer trust and loyalty }\end{array}$ & 12 & $\begin{array}{l}\text { Was it easy to make comparisons with other prod- } \\
\text { ucts and prices in order to reach your decision? }\end{array}$ \\
\hline $\begin{array}{l}\text { Techno-stress, user-friendly system, cus- } \\
\text { tomer familiarity }\end{array}$ & 13 & $\begin{array}{l}\text { Did you easily understand what the icons repre- } \\
\text { sented? }\end{array}$ \\
\hline Self-service, time factor & 14 & $\begin{array}{l}\text { Do you think you would have saved more time by } \\
\text { face-to-face interaction? }\end{array}$ \\
\hline Self-service, time factor & 15 & $\begin{array}{l}\text { Do you think your problem would have been re- } \\
\text { solved faster with face-to-face interaction? }\end{array}$ \\
\hline Self-service, time factor, customer support & 16 & $\begin{array}{l}\text { Did you receive efficient online assistance? In what } \\
\text { form was there assistance: documents, videos, call } \\
\text { centre? } \\
\text { Which form of assistance is most effective in your } \\
\text { opinion? }\end{array}$ \\
\hline Risk & 17 & $\begin{array}{l}\text { In your view, how significant is the contribution } \\
\text { that online shopping makes to fraud and identity } \\
\text { theft? }\end{array}$ \\
\hline Satisfying customer needs & 18 & $\begin{array}{l}\text { Do you feel that you saved money by shopping } \\
\text { online? }\end{array}$ \\
\hline Customer familiarity & 19 & How often do you shop online? \\
\hline $\begin{array}{l}\text { Satisfying customer needs, elimination of } \\
\text { barriers, customisation }\end{array}$ & 20 & $\begin{array}{l}\text { Is there a specific line of products that you prefer } \\
\text { purchasing online rather than in a physical store? }\end{array}$ \\
\hline Risk & 21 & $\begin{array}{l}\text { Was the confirmation process satisfying/comforting } \\
\text { to you? }\end{array}$ \\
\hline Satisfying customer needs & 22 & $\begin{array}{l}\text { Please comment on your overall online shopping } \\
\text { experience. }\end{array}$ \\
\hline Customer trust, loyalty and social influence & 23 & Are you confident to refer this e-service to others? \\
\hline
\end{tabular}

Interview questions were adapted from:

1. Collier and Bienstock 64 in the environment of e-retailing;

2. Park and Kim 65] in the environment of online shopping;

3. Tarafdat et al. [3] in the environment of information and communication technologies (ICT);

4. Lee and Joshi [2] in the environment of online shopping. 